\title{
Distribution of mega fauna on sulfide edifices on the Eastern Lau Spreading Center and Valu Fa Ridge
}

\author{
Arunima Sen ${ }^{\mathrm{a}, *}$, Erin L. Becker ${ }^{\mathrm{a}}$, Elizabeth L. Podowski ${ }^{\mathrm{a}, 1}$, Leslie N. Wickes ${ }^{\mathrm{a}, 2}$, Shufen Ma ${ }^{\mathrm{b}, 3}$, \\ Katherine M. Mullaugh ${ }^{\mathrm{b}, 4}$, Stéphane Hourdez ${ }^{\mathrm{b}}$, George W. Luther III $^{\mathrm{c}}$, Charles R. Fisher ${ }^{\mathrm{a}}$ \\ a Department of Biology, Pennsylvania State University, 208 Mueller Building, University Park, PA 16802, USA \\ b Station Biologique de Roscoff, CNRS-UPMC, UMR 7144, Génétique des Adaptations au Milieu Extrême, 29680 Roscoff, France \\ c School of Marine Science and Policy, University of Delaware, 700 Pilottown Road, Lewes, DE 19958, USA
}

Hydrothermal vent sulfide edifices contain some of the most extreme thermal and chemical conditions in which animals are able to live. As a result, sulfide edifices in the East Pacific Rise, Juan de Fuca Ridge, and Mid Atlantic Ridge vent systems often contain distinct faunal assemblages. In this study, we used high-resolution imagery and in-situ physico-chemical measurements within the context of a Geographic Information System (GIS) to examine community structure and niche differentiation of dominant fauna on sulfide edifices in the Eastern Lau Spreading Center (ELSC) and Valu Fa Ridge (VFR) in the Western Pacific Ocean. Our results show that ELSC and VFR sulfide edifices host two distinct types of communities. One type, that covers the majority of sulfide edifice faces, is overall very similar to nearby lava communities and biomass is dominated by the same chemoautotrophic symbiont-containing molluscs that dominate lava communities, namely the provannid gastropods Alviniconcha spp. and Ifremeria nautilei and the mytilid bivalve Bathymodiolus brevior. The spatial distribution of the dominant molluscs is often a variation of the pattern of concentric rings observed on lavas, with Alviniconcha spp. at the tops of edifices where exposure to vent flow is the highest, and I. nautilei and B. brevior below. Our physico-chemical measurements indicate that because of rapid dispersion of vent fluid, habitable area for symbiont-containing fauna is quite limited on sulfide edifices, and the realized niches of the mollusc groups are narrower on sulfide edifices than on lavas. We suggest that competition plays an important role in determining the realized distributions of the mollusc groups on edifices. The other habitat, present in small patches of presumably hot, new anhydrite, is avoided by the dominant symbiont-containing molluscs and inhabited by crabs, shrimp and polynoids that are likely more heat tolerant. The ratio of sulfide concentration to temperature anomaly of vent fluids was significantly different between sulfide edifice sites and lava sites in the southern vent fields but not in the northern vent fields. We suggest that this is due to increased sulfide consumption by a large microbial consortium associated with the more friable andesitic lava substrates in the south.

\section{Introduction}

The Lau Back-arc Basin is situated in the Western Pacific between the nations of Fiji and the Kingdom of Tonga. Two regions of the Lau

\footnotetext{
* Corresponding author: Tel.: +1 814863 8360; fax: +1 8148659131.

E-mail address: axs1026@psu.edu (A. Sen).

${ }^{1}$ Present address: Department of Landscape Architecture, 1190 Franklin Boulevard-230 Lawrence Hall, 5234 University of Oregon, Eugene, OR 97403-5234, USA.

2 Present address: Grice Marine Laboratory, College of Charleston, 205 Fort Johnson Road, Charleston, SC 29412, USA.

${ }^{3}$ Present address: Department of Earth and Planetary Science, University of California, Berkeley, CA 94720, USA.

${ }^{4}$ Present address: University of North Carolina Wilmington, Wilmington, NC 28403, USA
}

Basin, the Eastern Lau Spreading Center (ELSC, from $\sim 19^{\circ} \mathrm{S}$ to $\sim 21^{\circ} \mathrm{S}$ ) and the Valu Fa Ridge (VFR, from $\sim 21^{\circ} \mathrm{S}$ to $23^{\circ} \mathrm{S}$ ), are located between a remnant arc (Lau Ridge) and an active volcanic arc (Tofua Volcanic Arc), west of the Tonga-Kermadec Trench (Fig. 1). These regions have been the focus of integrated biological and geological studies because crustal chemistry, spreading rates, lithospheric thickness and mantle properties all vary from north to south along the spreading center (Baker et al., 2006; Ferrini et al., 2008; Martinez et al., 2006; Pearce et al., 1994; Taylor et al., 1996, Tivey et al., 2012). Moving north to south along the ELSC and VFR (hereafter ELSC/VFR), distance from the active volcanic arc decreases from about $110 \mathrm{~km}$ to within $40 \mathrm{~km}$ (Ferrini et al., 2008; Martinez et al., 2006). Hydrothermal plume incidence decreases from north to south (Baker et al., 2006; Ferrini et al., 2008; Martinez et al., 2006), as do spreading rates, from about $97 \mathrm{~mm} / \mathrm{yr}$ in the 


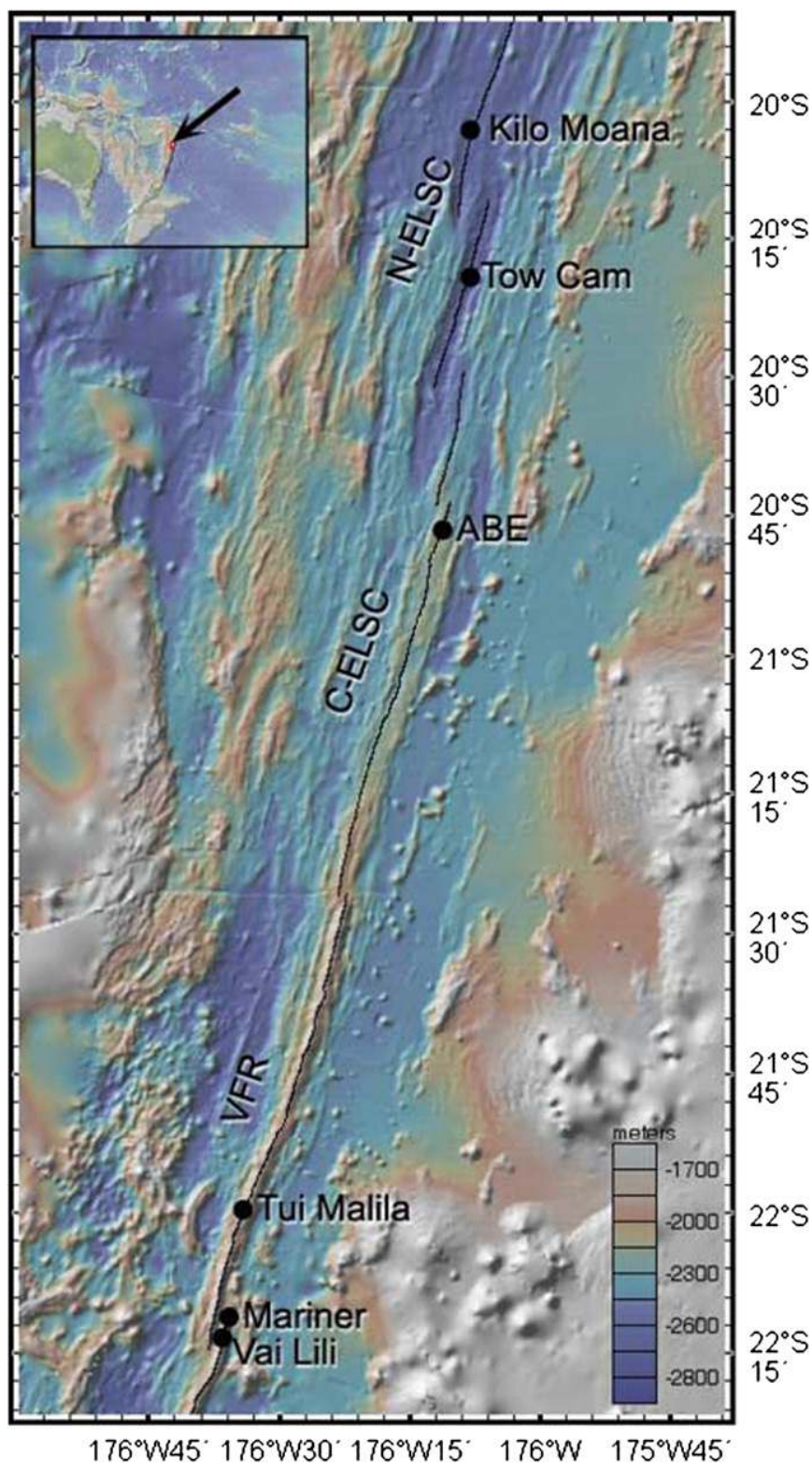

Fig. 1. Map of the vent fields of the Eastern Lau Spreading Center and Valu Fa Ridge (courtesy Ferrini et al., Variable morphologic expression of volcanic, tectonic, and hydrothermalprocesses at six hydrothermal vent fields in the Lau back-arc basin. Geochemistry Geophysics Geosystems 9 (7), 2008. Copyright (2008) American Geophysical Union. Reproduced with permission of American Geophysical Union).

north to $39 \mathrm{~mm} / \mathrm{yr}$ in the south (Ferrini et al., 2008). Crustal thickness follows the opposite trend, with thin lithospheric crusts present in the north that nearly double in thickness to the south (Martinez et al., 2006). The crustal morphology also changes quite dramatically, with the northern sites being characterized by deep, flat axial basins and containing more faulting and fissuring than the southern sites, which are characterized by shallow, peaked ridges (Ferrini et al., 2008; Martinez et al., 2006).

Differences in the physical properties of lavas have been suggested to contribute to differences in the diffuse flow communities between northern and southern sites (Podowski et al., 2010). The northern sites of the ELSC are characterized by lobate pillow lavas of tholeiitic basalt, similar to mid-ocean ridge basalts (Fouquet et al., 1991a). The southern sites, however, have more complex and varied lavas, with a mixture of pillows and andesites
(Ferrini et al., 2008; Fouquet et al., 1991a; Martinez et al., 2006). The andesitic lavas of the south are more porous, crumbly and have higher silica content than the pillow basalts of the north (Ferrini et al., 2008; Pearce et al., 1994). The proximity to the subducting slab and the presence of an axial magma chamber (only under southern sites) lead to a much higher gas content in the magma. This is thought to be responsible for making the lavas in the south more brecciated and vesicular (Fouquet et al., 1991a,b; Martinez et al., 2006; Pearce et al., 1994). North-tosouth differences in chemistry and acidity of venting fluids are also attributed to the distance from the subducting slab and the presence/absence of the magma chamber (Baker et al., 2006; Gartman et al., 2011; Luther et al., 2012; Martinez et al., 2006; Mottl et al., 2011). The along-strike changes in the geochemistry of the lavas and hydrothermal fluid on the ELSC and VFR provide an excellent natural laboratory to investigate the interactions between the animal communities and the rock substrate and fluid chemistry.

A number of researchers have studied hydrothermal vents through still and video imagery as well as within the context of a Geographical Information System (Copley et al., 1997, 1999, 2007; Cuvelier et al., 2011; Fabri et al., 2011; Podowski et al., 2009, 2010; Sarrazin and Juniper, 1999; Tsurumi, 1998). Deep-sea vents are extremely difficult to access and these methods represent an uninvasive and relatively quick way in which these systems can be studied. Podowski et al. (2009, 2010) and Kim and Hammerstrom (2012) used these methods to examine the hydrothermal vent communities on lavas of the ELSC/VFR within the context of the geological and thermo-chemical gradients present in this region. However, the communities present on hydrothermal vent sulfide edifices in the Western Pacific region have not been well studied and have been characterized variously as dominated by one species of gastropod (Both et al., 1986; Stein et al., 1988), consisting of 'diverse assemblages' (Tufar, 1989), and 'abiotic' (Desbruyères et al., 1994). Our goal was to characterize these sulfide edifice communities, compare them to the communities found on the surrounding lavas, and to explore the roles of abiotic factors and biological interactions in shaping them. Abiotic factors can influence the structure of hydrothermal vent communities because distributions of symbiontcontaining fauna are strongly correlated with hydrothermal conditions, as are the distributions of other vent fauna, albeit often at very different scales (Govenar, 2010). Gradients in vent fluid temperature and chemistry are quite steep on sulfide edifice structures where temperatures can change by over $100^{\circ} \mathrm{C}$ within just a few centimeters (Harmsen et al., 1997; Jannasch, 1995; Takai et al., 2008; Tivey and McDuff, 1990). Additionally, biological interactions have been shown to shape hydrothermal vent communities (Lenihan et al., 2008; Micheli et al., 2002), including those on sulfide edifice structures (Levesque et al., 2003). Here, we used spatially explicit in situ physico-chemical measurements paired with high-resolution photo mosaics of Lau Basin sulfide edifices to address how both biotic and abiotic factors affect community structure as well as refine our understanding of the physiological ecology of the dominant fauna associated with diffuse hydrothermal flow on sulfides and lavas in the Lau Basin.

\section{Methods and materials}

\subsection{Imaging and mosaicking}

We collected photographic and physico-chemical data from eight sulfide edifices (sulfide edifice assessment sites) from the four main vent fields along the ELSC/VFR axis: Kilo Moana (KM), Tow Cam (TC), and ABE on the ELSC and Tu'i Malila (TM) on the VFR (Table 1 and Fig. 1). All data collection was conducted in September 
Table 1

Characteristics of the nine sulfide edifice assessment sites and the seven lava assessment sites comparisons were made with.

\begin{tabular}{|c|c|c|c|c|c|c|}
\hline Site & Vent field & Markers & Latitude & Longitude & $\begin{array}{l}\text { Depth } \\
(\mathrm{m})\end{array}$ & $\begin{array}{l}\text { Height/ } \\
\text { area }\end{array}$ \\
\hline KM1C & $\begin{array}{l}\text { Kilo } \\
\text { Moana }\end{array}$ & $\mathrm{E}$ & -20.05323 & -176.13369 & 2618 & $15.5 \mathrm{~m}$ \\
\hline KM2C & $\begin{array}{l}\text { Kilo } \\
\text { Moana }\end{array}$ & $\mathrm{D}$ & -20.05408 & -176.13363 & 2620 & $4.6 \mathrm{~m}$ \\
\hline TC1C & Tow Cam & $\mathrm{JJ}$ & -20.31620 & -176.13651 & 2720 & $3.5 \mathrm{~m}$ \\
\hline ABE1C & $\mathrm{ABE}$ & G1 & -20.76124 & -176.19060 & 2141 & $2.5 \mathrm{~m}$ \\
\hline ABE2C & $\mathrm{ABE}$ & $\mathrm{AA}$ & -20.76578 & -176.19314 & 2131 & $2.6 \mathrm{~m}$ \\
\hline ABE3C & $\mathrm{ABE}$ & G2 & -20.76120 & -176.19061 & 2141 & $3.4 \mathrm{~m}$ \\
\hline ABE4C & $\mathrm{ABE}$ & G3 & -20.76125 & -176.19058 & 2141 & $1.5 \mathrm{~m}$ \\
\hline TM1C & $\begin{array}{l}\text { Tu'i } \\
\text { Malila }\end{array}$ & 62 back & -21.98803 & -176.56777 & 1894 & $2.2 \mathrm{~m}$ \\
\hline TM2C & $\begin{array}{l}\text { Tu'i } \\
\text { Malila }\end{array}$ & 62 front & -21.98799 & -176.56783 & 1894 & $2.2 \mathrm{~m}$ \\
\hline KM1 & $\begin{array}{l}\text { Kilo } \\
\text { Moana }\end{array}$ & 29 & -20.05266 & -176.13384 & 2615 & $34.9 \mathrm{~m}^{2}$ \\
\hline KM2 & $\begin{array}{l}\text { Kilo } \\
\text { Moana }\end{array}$ & $\begin{array}{l}54,55, \\
56\end{array}$ & -20.05388 & -176.13363 & 2620 & $39.5 \mathrm{~m}^{2}$ \\
\hline TC1 & Tow Cam & 31 & -20.31667 & -176.13620 & 2706 & $17.9 \mathrm{~m}^{2}$ \\
\hline TC2 & Tow Cam & $64, \mathrm{~J}$ & -20.31635 & -176.13645 & 2723 & $9.8 \mathrm{~m}^{2}$ \\
\hline ABE1 & $\mathrm{ABE}$ & $\begin{array}{l}50,51, \\
52\end{array}$ & -20.76319 & -176.19133 & 2150 & $34.7 \mathrm{~m}^{2}$ \\
\hline ABE2 & $\mathrm{ABE}$ & 32,49 & -20.76131 & -176.19041 & 2140 & $4.6 \mathrm{~m}^{2}$ \\
\hline TM1 & $\begin{array}{l}\text { Tu'i } \\
\text { Malila }\end{array}$ & $\begin{array}{l}42,43, \\
44\end{array}$ & -21.98916 & -176.56827 & 1884 & $19.7 \mathrm{~m}^{2}$ \\
\hline
\end{tabular}

2006 with the remotely operated vehicle (ROV) 'Jason II' aboard the $\mathrm{R} / \mathrm{V}$ Melville. The edifices were not chosen randomly, but rather, based on accessibility and the presence of animal assemblages that included at least some symbiont-containing fauna indicative of hydrothermal vent activity. The sulfide edifice assessment sites were named as in Podowski et al. (2010), with a two or three-letter designation for the vent field followed by a sequential number and then the letter ' $C$ ' to represent chimneys (Table 1 ). In the northernmost vent field, Kilo Moana, two edifices were chosen for study, KM1C and KM2C. KM1C is the tallest of the edifices in this study, rising about $15.5 \mathrm{~m}$ above the seafloor. $\mathrm{KM} 2 \mathrm{C}$ is an edifice consisting of two structures side by side, one only about a meter high, while the other reaches a height of about $4.6 \mathrm{~m}$. One edifice from the Tow Cam vent field was used in this study, TC1C, which is approximately $3.5 \mathrm{~m}$ high. The $\mathrm{ABE}$ vent field hosted a large number of hydrothermal edifices in close proximity to each other. Therefore, four edifices from this vent field were surveyed for this study. ABE1C is a multi-spired edifice in which the tallest spire reaches a height of about $2.5 \mathrm{~m}$. ABE2C is a very wide edifice and also contains multiple spires with a maximal height of $2.6 \mathrm{~m}$. $\mathrm{ABE} 3 \mathrm{C}$ is a narrow, single spire about $3.5 \mathrm{~m}$ tall. $\mathrm{ABE} 4 \mathrm{C}$ is a fairly narrow edifice and the shortest used in this study, reaching a height of about $1.5 \mathrm{~m}$. One edifice from the vent field, Tu'i Malila, was used in this study but we were able to photograph both sides of this structure. Therefore they have been included here as TM1C and TM2C. This edifice is about $2.2 \mathrm{~m}$ tall.

Imagery and mosaicking of the sulfide edifice assessment sites followed the procedure outlined in Podowski et al. (2009, 2010), with the exception that the camera was positioned so that it was facing forward instead of downward. Images were collected by moving the ROV up, down, left and right, while maintaining a constant heading, to image the entire edifice. Two sets of overlapping images were taken at different distances from the edifices. The images in the farther set were stitched ('mosaicked') together using a customized Matlab program (Pizarro and Singh, 2003) to produce a seamless mosaic of each sulfide edifice assessment site. The mosaic was then imported into ArcGIS, georeferenced and the fauna digitized (see below). The closer set of images was used for fauna identification. The exact distances from which the photos were taken are not known, but scale was added during the georeferencing stage as described below.

\subsection{Georeferencing}

Because sulfide edifices are vertical and often narrow features, many edifice mosaics consisted of a single line of overlapping photographs. The ROV's navigation system records altitude at every second during a lowering (as well as UTM coordinates and a number of other parameters), and this was used to derive a coordinate system to georeference mosaics in ArcGIS and provide scale for analyses. The centers of two overlapping individual photographs were marked on the mosaic and the difference in altitude between the marked centers of the two pictures was used to calculate distances to the corners of the mosaic. The corners were georeferenced because using only the centers of photographs in a single line flattened the mosaic into a thin strip with no width component. For mosaics that consisted of two or more vertical lines of photographs, the horizontal component was derived from the UTM coordinates using the formula $x=\left(U T M x^{2}+U T M y^{2}\right)^{1 / 2}$. It should be noted that using this system for our analyses resulted in treating sulfide edifices as two-dimensional structures and total substrate area was underestimated because surface topography was not considered in the analyses.

\subsection{Digitization of fauna}

Using the closer set of images for identification, fauna were manually digitized onto the georeferenced mosaic within ArcMap 9.0. Aggregated fauna (i.e., the snails Alviniconcha spp. and Ifremeria nautilei, the mussels Bathymodiolus brevior, and several species of barnacles) were digitized as polygons (areas) since these animals form dense aggregations in which individuals can be stacked on top of one another and difficult to enumerate. At least three different species of Alviniconcha have recently been identified on the ELSC/VFR (Beinart et al., in press). They cannot be differentiated by imagery alone and therefore are referred to as Alviniconcha spp. for the purpose of this study. Similarly, the different species of barnacles could not be reliably differentiated in the images and therefore the 'barnacle' category may include up to three different orders of barnacles known to occur in the ELSC. Stalked barnacles (Vulcanolepas sp.), however, were distinctive enough to be included as a separate category, though only two individuals on one edifice were observed in this study. The molluscs Alviniconcha spp., I. nautilei and B. brevior all contain sulfide oxidizing bacteria in their gills and dominate the biomass at Lau vents (Podowski et al., 2009, 2010). Therefore, these three faunal groups are collectively referred to as the dominant symbiont-containing molluscs.

All other fauna were digitized as points. These animals are referred to as solitary fauna. The buccinid snail, Enigmaticolus desbruyeresi, the sea cucumber Chiridota hydrothermica, the zoarcid fishes Thermarces sp. and Thermobiotes mytilogeiton, the squat lobster Munidopsis lauensis and the polynoids Branchinotogluma segonzaci, Branchinotogluma trifurcus, Branchinotogluma sp. nov., Harmothoe sp., Thermopolynoe branchiata and Levensteiniella raisae could be consistently identified to the species level. Although limpets were visible in some mosaics, the resolution was not sufficient to recognize these small animals in all photos and they were not considered in this analysis. The other solitary species were classified by larger taxonomic groups. At least seven different 
species of anemones exist on the ELSC. Neither Chondrophellia orangina nor Zoanthidae sp. were present on edifices. The others, Cyananthea hourdezi, Actinostolidae sp., Alvinactis chessi, Sagartiogeton erythraios and Amphianthus sp. (Zelnio et al., 2009), cannot be reliably identified from photographs and were grouped together under one category. Four different species of shrimp, Alvinocaris komaii, Lebbeus sp., Chorocaris vandoverae and Nautilocaris saintlaurentae, could occasionally, but not routinely, be identified, so all four species were grouped together for statistical analyses. The Bythograeid crabs could be identified as Austinograea williamsi or Austinograea alayseae only if the inside of the cheliped was visible. Podowski et al. (2010) found no significant differences in the distributions of these two species in diffuse flow, and although we identified the species when possible, we grouped them together as Austinograea spp. for the purpose of statistical analyses.

\subsection{In-situ chemistry}

In-situ voltammetry was used to measure hydrogen sulfide $\left(\mathrm{H}_{2} \mathrm{~S}\right)$ and oxygen concentrations at a number of discrete locations within each sulfide edifice assessment site (Luther et al., 2001, 2008; Podowski et al., 2009, 2010). At each location, the voltammetric analyzer took 4-7 scans from which minimum, maximum, average and median sulfide and oxygen concentrations were calculated for each location. The minimum detectable and quantifiable concentrations of sulfide were $0.2 \mu \mathrm{mol} \mathrm{L}{ }^{-1}$. Undetectable sulfide was treated as half the detectable concentration $\left(0.1 \mu \mathrm{mol} \mathrm{L}^{-1}\right)$ as per Podowski et al. (2009). The minimum detectable concentration of oxygen was $5 \mu \mathrm{mol} \mathrm{L}{ }^{-1}$ and the minimum quantifiable concentration of oxygen was $15 \mu \mathrm{mol} \mathrm{L}^{-1}$. Consistent with Podowski et al. (2009), half the minimum detectable concentration $\left(2.5 \mu \mathrm{mol} \mathrm{L}^{-1}\right)$ was used for points with undetectable oxygen and points with detectable but not quantifiable oxygen concentrations were treated as the average of detectable and quantifiable limits $\left(10 \mu \mathrm{mol} \mathrm{L}^{-1}\right)$ for statistical analyses. In addition to sulfide and oxygen, the voltammetry wand had a thermocouple to measure temperature. Therefore, minimum, maximum, average and median measurements of temperature were calculated from the 4 to 7 scans for each location. In order to increase the coverage of an edifice and increase the resolution of assessment of vent fluid dynamics, additional temperature measurements were taken with the Jason temperature probe on some edifices. In addition to generally increasing the density of measurements on edifices, locations that appeared to be hot (usually due to visible shimmering water) were measured with the Jason temperature probe to prevent damage to the voltammetry wand that had a maximum exposure limit of about $60^{\circ} \mathrm{C}$. Local ambient temperature was calculated for each site based on the Jason CTD data. The ambient temperature for each site was subtracted from temperature measurements to obtain the temperature anomaly for every location. Temperature anomalies instead of raw temperatures were used in all statistical analyses.

The dataset used in Podowski et al. (2010), which characterized seven lava assessment sites at the same four vent fields of the ELSC and the VFR, was used for analyses that compared sulfide edifice and lava assessment sites.

\subsection{Statistical and spatial analyses}

Relative percent covers of each of the aggregated fauna and densities of solitary fauna were calculated within ArcView 9.0 and used for comparisons of community structure among sulfide edifice sites and between sulfide edifice and lava sites.

In order to test if the diffuse vent fluid bathing the animals differed between edifice and lava sites, as well as between northern and southern sites, the relationship between maximum sulfide and maximum temperature anomaly at each point was examined through regression analysis for both edifice and lava sites, separated by northern and southern groupings.

Measurements from all edifices were grouped together and pairwise Mann-Whitney comparisons were conducted to assess whether the chemistry and temperature associated with the three dominant mollusc groups differed between groups/species on edifices. Furthermore, pairwise Mann-Whitney comparisons were conducted to examine whether the chemical and thermal measurements associated with the dominant symbiont-containing mollusc groups were different between lava and sulfide edifice assessment sites. In each of the pairwise Mann-Whitney comparisons, a Bonferroni corrected p-value was used (Dunn, 1961). Box plots were constructed to visualize the chemical and thermal habitats of the foundation species on edifices as well as lavas.

Three Bray-Curtis dissimilarity matrices were constructed to assess the variation in community structure among the sites. One was based on the overall percent cover of aggregated fauna, another on relative percent cover of aggregated fauna and the third on the densities of solitary fauna. For this analysis, the data were fourth root transformed to decrease bias towards dominant taxa (Clarke and Warwick, 2001). Dendrograms based on group average linkage were constructed for each dataset to visualize the clustering of sites. Additionally, to test the probability of these clusters arising from chance alone, analysis of similarity (ANOSIM) was carried out for each matrix (Clarke, 1993) with location (north vs. south) and habitat (edifice vs. lava) as the factors tested.

\section{Results and discussion}

\subsection{Chemistry and temperature relationships}

The slope of maximum sulfide concentration to maximum temperature anomaly in the northern sulfide edifice assessment sites (slope $=5.6$ ) was significantly higher than the southern sulfide edifice assessment sites (slope $=3.7 ; p=0.001$; Fig. 2 ): diffuse fluid

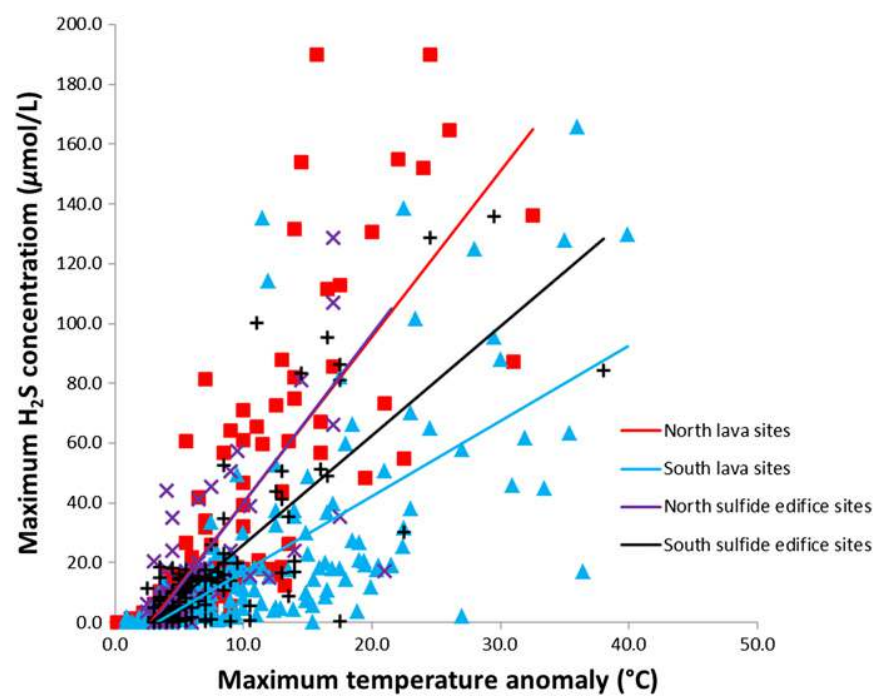

Fig. 2. Maximum sulfide concentration vs. maximum temperature anomaly for edifices and lavas, separated by location. Each point represents the maxumum sulfide concentration and temperature anamoly measured at a single point: $\boldsymbol{\square}=$ northern lava sites, $\boldsymbol{\Delta}=$ southern lava sites, $x=$ northern edifice sites, and $+=$ southern edifice sites. The slope of northern lava $(y=5.71 x-4.78)$ is significantly higher than the slope of southern lava $(y=2.42 x-3.44)$ at $p<0.001$. The slope of northern edifice $(y=5.64 x-3.12)$ is significantly higher than the slopes of both southern lava and southern edifice $(y=3.66 x-1.64)$ at $p<0.001$ and $p=0.001$, but not significantly different from the slope of nothern lava at $p=0.914$. The slope of southern edifice is higher than the slope of southern lava at $p<0.001$ and lower than the slope of basalt lava at $p<0.001$. 
in the north on sulfide edifices contained more sulfide at a given temperature than fluid in the south. Mottl et al. (2011) found that sulfide concentrations in endmember fluid decrease from north to south along the ELSC/VFR with the highest concentrations in endmember fluid at Tu'i Malila being three times lower than concentrations measured in Kilo Moana. The decrease in sulfide concentrations in endmember fluid from north to south along the ELSC to the VFR is consistent with the higher sulfide to temperature ratios observed in the north (Gartman et al., 2011; Luther et al., 2012).

In addition to examining the sulfide to temperature ratios of the fluids from edifices, we compared these ratios to those of the fluids from the lava sites studied by Podowski et al. (2010). The slope of maximum sulfide concentration to maximum temperature anomaly in the northern vent fields was not significantly different between lava and sulfide edifice assessment sites (slope $=5.7$ for northern lavas and 5.6 for northern edifices; $p=0.91$; Fig. 2). However, the slope was significantly higher for edifices than for lavas in the southern vent fields (slope $=3.7$ for southern edifices and 2.4 for southern lavas, $p<0.0001$, Fig. 2). Therefore, these ratios differ between edifices and lava sites in the south but are nearly identical between edifices and lava sites in the north (Fig. 2). This difference in ratios is either due to differences in the lavas or edifices, or both, between the two areas. Since the composition of lavas is known to change from north to south, we suggest the difference is more likely due to variations in the interactions of the lavas with hydrothermal flow than to dissimilarities in the edifices. Two potential mechanisms may contribute to the different relationships between lavas and edifices in the north and south. First, conductive cooling of vent fluid before it exits the substrate could occur to equal degrees in edifices and under lavas in the north, but occur to a higher degree in edifices than lavas in the south. We know of no data or logic that might support this hypothesis. The second possibility is that sulfide consumption in edifices is the same in the north and south, but sulfide consumption while hydrothermal fluid passes through lavas is higher in the south than in the north. There are data to support this hypothesis; the andesitic lavas at our southern study sites were more crumbly and brecciated than the pillow basalts common on the more northern sites, and Podowski et al. (2010) found significant differences in the small-scale spatial structure of diffuse venting from north to south. The spatial correlation among measurements less than $60 \mathrm{~cm}$ apart in the south was suggested to result from near-surface dispersion of flow by the more porous and gravel-like andesitic basalt substrate in the south. This substrate could provide larger surface areas for microbes in an environment where sulfide oxidizers could flourish. This, in turn, would reduce the sulfide to temperature ratios in communities on more andesitic lavas and explain the differences in the relations between the different lavas and edifices. Consistent with this hypothesis is the fact that we were unable to detect spatial autocorrelation between measurements on edifices for either temperature or chemistry data, suggesting that similar to basaltic lavas, fluid flow from edifices is largely in the form of point source emissions rather than more diffuse release from the surface of the edifice.

\subsection{Communities}

We identified one specialized sulfide edifice community type that occurs occasionally along the ELSC/VFR. It occurs in small, white patches on what appear to be new and relatively small sulfide structures or parts of structures and was also found on two large active horizontal flanges in Tu'i Malila. This community includes at least two species of paralvinellid polychaeates, Paralvinella unidentata and Paralvinella fijiensis that are not distinguishable by imagery, the polynoid B. segonzaci, shrimp (either C. vandoverae or Nautilocaris saintlarentae), and Bythograeid crabs (Fig. 3). One individual of B. trifurcus was also observed in this community. The dominant symbiont-containing molluscs were rarely observed here. The paralvinellid worms were found exclusively in this habitat and the polynoids show a species-based preference or avoidance of these white patches. On average, these white patches covered $17 \%$ of edifice surfaces, but $90 \%$ of all individuals of B. segonzaci ( 320 out of a total of 357) were present within them. Individuals of $B$. segonzaci not directly in the habitat were just adjacent and not more than a few centimeters away. The one individual of $B$. trifurcus observed in this study was also present in the white patch habitat. The other species of polynoids observed in this study (10 individuals of Harmothoe sp., 3 individuals of $L$. raisae, 2 individuals of $T$. branchiata and 1 individual of Branchinotogluma sp. nov.) were never observed on these white patches. Unlike the paralvinellid worms and the $B$. segonzaci polynoids, other animals, such as shrimp, occupy these areas and the rest of sulfide edifice walls equally; they were found on both types of edifice surfaces in approximately equal ratios. The white coloration of the substrate these communities are located on could be due to the formation of anhydrite (calcium sulfate), which is generally considered to be the initial stage in precipitation and formation of sulfide structures (Haymon, 1983; Tivey and Delaney, 1986; Tivey and McDuff, 1990; Graham et al., 1988; Koski et al., 1988). The edifices TC1C, KM1C and the two faces of the TM edifice, which were largely devoid of such white patches, hosted the lowest numbers of B. segonzaci. It appears that though these white patches are avoided by the dominant symbiont-containing molluscs, they are invaded opportunistically by some groups such as Bythograeid crabs and shrimp, while other species such as $B$. segonzaci and paralvinellid worms are specialized for, and largely restricted to, this habitat. We were able to obtain only a few temperature measurements on these surfaces and these measurements indicated that the surfaces of these patches can be quite hot (above $80^{\circ} \mathrm{C}$ ). The high temperatures and the proximity of either black 'smoke' or shimmering water common in these areas suggest that sulfide levels are also high and oxygen levels are low (Luther et al., 2001). However, detailed physicochemical measurements will be needed to adequately characterize the thermo-chemical conditions in this microhabitat. Nonetheless, it is likely that the animals in these patches are living at the limits of thermal and chemical tolerances for metazoans (Dilly et al., 2012; Fisher, 1998; Girguis and Lee, 2006; Lee, 2003). Despite the presence of this edifice specific community, the majority of edifice surfaces were dominated by assemblages that were quite similar to those on the surrounding lavas. Alviniconcha spp., I. nautilei and B. brevior comprised the bulk of the biomass at all assessment sites (Desbruyères et al., 1994; Podowski et al., 2009, 2010). All the covers of the aggregated fauna on lavas and edifices are compiled in Table 2. Five of the nine sulfide edifice assessment sites in this study displayed a pattern in which the top zone of the edifice was occupied, sometimes exclusively, by Alviniconcha spp., girdled by a zone of I. nautilei and B. brevior below (Fig. 4). One edifice, KM1C, displayed a pattern of concentric rings at the base of the edifice, with Alviniconcha spp. in the middle, surrounded by I. nautilei and then by B. brevior (Mullaugh et al., 2008), a pattern which has been described on lavas (Desbruyères et al., 1994). Also similar to lava communities, barnacles occurred in large, dense aggregations on many edifices (Podowski et al., 2010). The colonial anemone, Zoanthidae sp. (Podowski et al., 2010) which covered large areas of lava on northern sites, was not present on any edifice assessment sites (Table 2).

Since one entire group of aggregated fauna was completely lacking on edifices, we expected edifice assessment sites to cluster together and separately from the lava assessment sites. We tested this by comparing our data to those collected by Podowski et al. (2010). However, cluster analysis for overall and relative percent covers of aggregated fauna did not group the assessment sites based on substrate (edifice vs. lava). Instead, for 
A

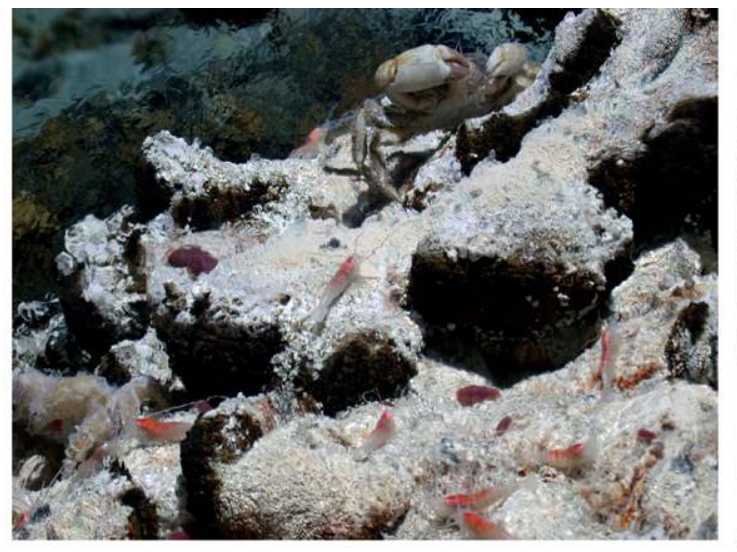

C

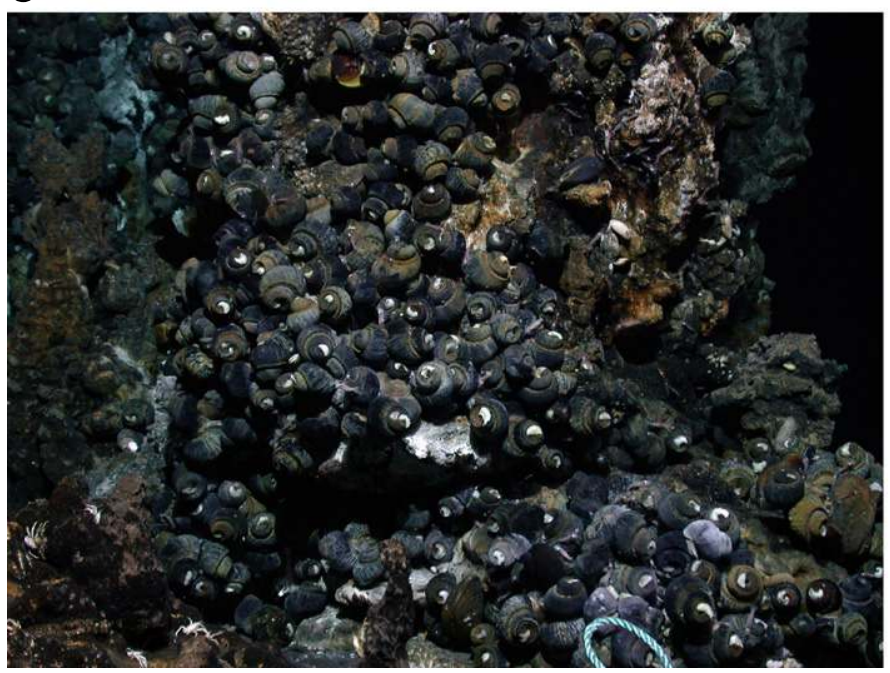

B

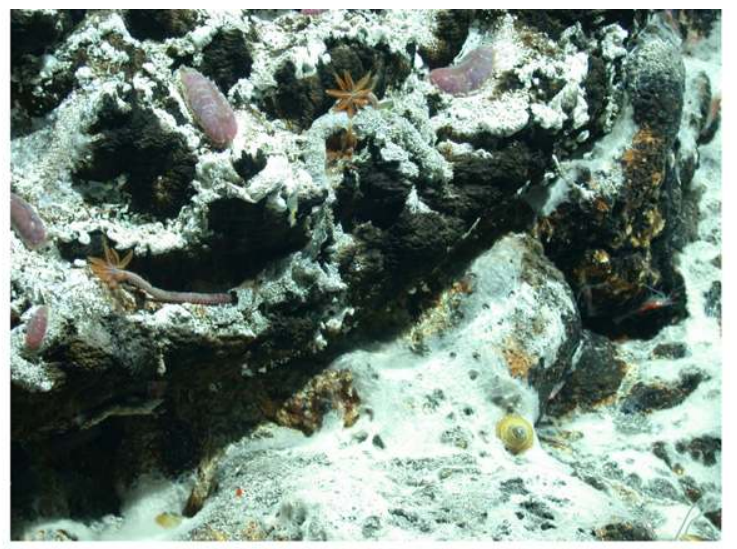

$\mathrm{D}$

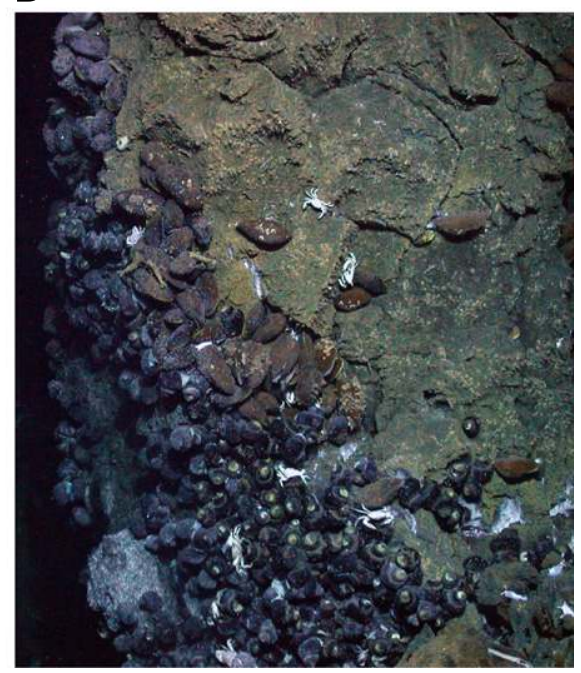

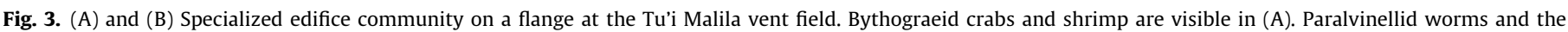
polynoid, Branchinotogluma segonzaci are visible in (B). (C) and (D) Typical lava communities present on edifices.

Table 2

Covers of aggregated fauna on all sulfide edifice and lava assessment sites.

\begin{tabular}{|c|c|c|c|c|c|c|c|c|c|c|c|c|c|c|c|c|}
\hline \multirow[t]{2}{*}{ Taxa } & \multicolumn{9}{|c|}{ Sulfide edifice assessment sites } & \multicolumn{7}{|c|}{ Lava assessment sites } \\
\hline & KM1C & KM2C & TC1C & ABE1C & ABE2C & ABE3C & ABE4C & TM1C & TM2C & KM1 & KM2 & TC1 & TC2 & ABE1 & ABE2 & TM1 \\
\hline Anemones & 0.5 & 0.0 & 0.0 & 8.0 & 1.0 & 3.5 & 2.1 & 0.0 & 0.0 & 7.7 & 11.1 & 74.9 & 0.3 & 0.0 & 9.8 & 1.3 \\
\hline Austinograea spp. & 1.7 & 3.3 & 0.0 & 3.1 & 7.3 & 3.5 & 23.3 & 2.4 & 1.7 & 3.6 & 3.5 & 3.0 & 2.2 & 4.1 & 4.0 & 3.0 \\
\hline B. segonzaci & 0.0 & 7.6 & 0.3 & 32.8 & 18.5 & 28.1 & 95.1 & 3.4 & 1.7 & 0.0 & 0.0 & 0.0 & 0.0 & 0.0 & 0.0 & 0.0 \\
\hline B. sp. nov. & 0.0 & 0.0 & 0.0 & 0.0 & 0.0 & 0.0 & 0.0 & 0.0 & 0.0 & 0.0 & 0.0 & 0.0 & 0.0 & 0.0 & 0.0 & 0.0 \\
\hline B. trifurcus & 0.0 & 0.0 & 0.0 & 0.0 & 0.0 & 0.0 & 0.0 & 0.0 & 0.0 & 0.0 & 0.0 & 0.0 & 0.0 & 0.0 & 0.0 & 0.0 \\
\hline C. hydrothermica & 1.0 & 0.0 & 0.0 & 0.0 & 0.0 & 0.0 & 0.0 & 0.0 & 0.0 & 0.4 & 0.3 & 0.4 & 0.0 & 0.0 & 0.0 & 0.0 \\
\hline Cladorhizid sponge & 0.0 & 0.0 & 0.0 & 0.0 & 0.0 & 0.0 & 0.0 & 0.0 & 0.0 & 0.0 & 0.1 & 0.0 & 0.0 & 0.0 & 0.0 & 0.0 \\
\hline E. desbruyeresi & 0.1 & 0.0 & 0.2 & 0.4 & 0.3 & 2.6 & 2.1 & 1.7 & 0.3 & 0.0 & 0.4 & 0.1 & 0.0 & 3.5 & 1.5 & 0.2 \\
\hline Harmothoe sp. & 0.2 & 0.0 & 0.0 & 0.0 & 0.1 & 0.0 & 0.0 & 0.0 & 0.0 & 0.0 & 0.0 & 0.0 & 0.0 & 0.0 & 0.0 & 0.0 \\
\hline L. raisae & 0.0 & 0.0 & 0.1 & 0.0 & 0.0 & 0.0 & 0.0 & 0.0 & 0.0 & 0.0 & 0.0 & 0.0 & 0.0 & 0.1 & 0.0 & 0.1 \\
\hline M. lauensis & 0.1 & 0.0 & 0.5 & 3.5 & 0.6 & 0.9 & 6.3 & 0.0 & 4.0 & 1.4 & 1.1 & 2.3 & 0.1 & 12.1 & 9.1 & 4.3 \\
\hline Paralvinella & 0.0 & 0.4 & 0.0 & 2.2 & 0.0 & 0.0 & 55.0 & 0.0 & 0.0 & 0.0 & 0.0 & 0.0 & 0.0 & 0.0 & 0.0 & 0.0 \\
\hline P. hirtella & 0.0 & 0.0 & 0.0 & 0.0 & 0.0 & 0.0 & 0.0 & 0.0 & 0.0 & 0.0 & 0.1 & 0.0 & 0.0 & 0.4 & 0.2 & 0.0 \\
\hline Phymorynchus sp. & 0.0 & 0.0 & 0.0 & 0.0 & 0.0 & 0.0 & 0.0 & 0.0 & 0.0 & 0.0 & 0.0 & 0.0 & 0.0 & 0.0 & 0.0 & 0.0 \\
\hline Shrimp & 11.2 & 71.9 & 62.3 & 19.5 & 51.7 & 78.3 & 0.0 & 131.3 & 40.7 & 1.5 & 13.7 & 4.0 & 0.0 & 8.6 & 0.5 & 4.4 \\
\hline T. branchiata & 0.0 & 0.0 & 0.0 & 0.0 & 0.0 & 0.0 & 0.0 & 0.0 & 0.0 & 0.0 & 0.0 & 0.0 & 0.0 & 0.0 & 0.0 & 0.0 \\
\hline Vulcanolepas sp. & 0.1 & 0.0 & 0.0 & 0.0 & 0.0 & 0.0 & 0.0 & 0.0 & 0.0 & 0.0 & 0.0 & 0.4 & 0.0 & 0.0 & 0.0 & 0.0 \\
\hline Zoarcidae & 0.0 & 0.0 & 0.0 & 0.0 & 0.3 & 0.0 & 2.1 & 0.0 & 0.0 & 0.1 & 0.0 & 0.0 & 0.0 & 0.2 & 0.4 & 0.0 \\
\hline
\end{tabular}

overall percent cover of aggregated fauna, the southern edifice and lava sites clustered together, while the northern lava and edifice sites displayed considerably more variation between sites (Fig. 5). Bray-Curtis analysis for relative percent cover also separated the southern sites as a cluster, although the edifice community at KM2C in the north grouped with the southern sites (Fig. 6). ANOSIM supported the clustering based on the aggregated faunal community structure (global $R=0.498, p=0.001$ and no permutations out of 999 

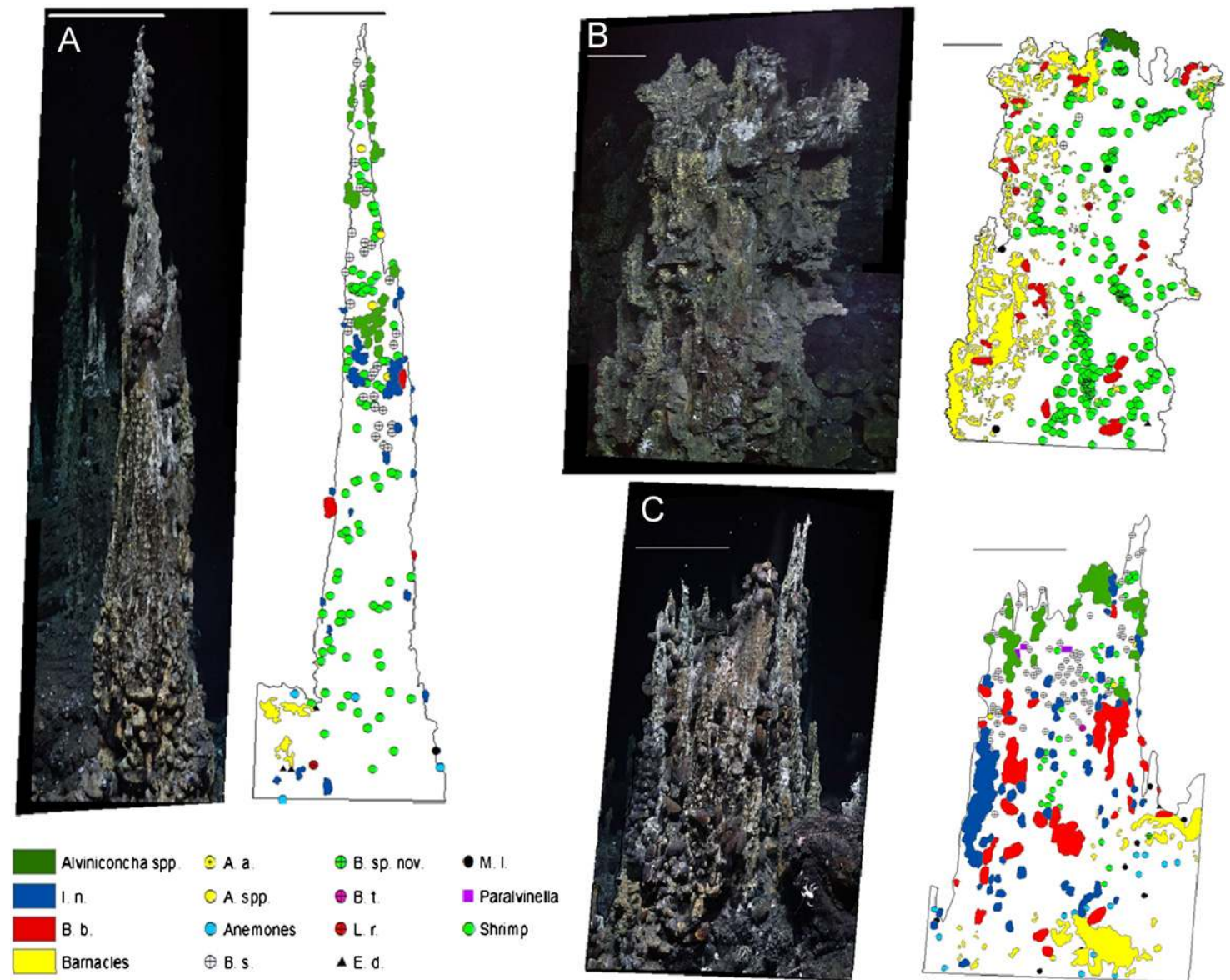

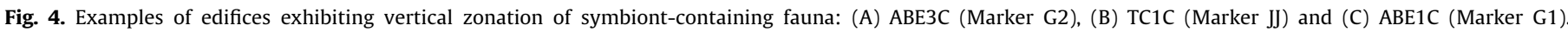

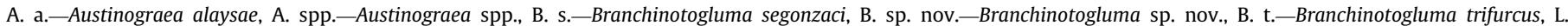
r.-Levensteiniella raisae, E. d.-Enigmaticolus desbruyeresi and M. 1.-Munidopsis lauensis. All scale bars represent $0.5 \mathrm{~m}$.

Table 3

Numbers of solitary fauna on all sulfide edifice and lava assessment sites.

\begin{tabular}{|c|c|c|c|c|c|c|c|c|c|c|c|c|c|c|c|c|}
\hline \multirow[t]{2}{*}{ Taxa } & \multicolumn{9}{|c|}{ Sulfide edifice assessment sites } & \multicolumn{7}{|c|}{ Lava assessment sites } \\
\hline & KM1C & KM2C & TC1C & ABE1C & ABE2C & ABE3C & ABE4C & TM1C & TM2C & KM1 & KM2 & TC1 & TC2 & ABE1 & ABE2 & TM1 \\
\hline Anemones & 19 & 0 & 0 & 18 & 7 & 4 & 1 & 0 & 0 & 168 & 500 & 2523 & 4 & 0 & 54 & 43 \\
\hline Austinograea spp. & 60 & 27 & 0 & 7 & 49 & 4 & 11 & 7 & 6 & 79 & 157 & 101 & 32 & 172 & 22 & 96 \\
\hline B. segonzaci & 1 & 63 & 2 & 74 & 124 & 32 & 45 & 10 & 6 & 0 & 0 & 0 & 0 & 0 & 0 & 0 \\
\hline B. sp. nov. & 0 & 0 & 0 & 1 & 0 & 0 & 0 & 0 & 0 & 0 & 0 & 0 & 0 & 0 & 0 & 0 \\
\hline B. trifurcus & 0 & 0 & 0 & 1 & 0 & 0 & 0 & 0 & 0 & 0 & 0 & 0 & 0 & 0 & 0 & 0 \\
\hline C. hydrothermica & 35 & 0 & 0 & 0 & 0 & 0 & 0 & 0 & 0 & 9 & 13 & 13 & 0 & 0 & 0 & 0 \\
\hline Cladorhizid sponge & 0 & 0 & 0 & 0 & 0 & 0 & 0 & 0 & 0 & 0 & 5 & 0 & 0 & 0 & 0 & 0 \\
\hline E. desbruyeresi & 2 & 0 & 1 & 1 & 2 & 3 & 1 & 5 & 1 & 0 & 20 & 5 & 0 & 146 & 8 & 7 \\
\hline Harmothoe sp. & 6 & 0 & 0 & 0 & 3 & 0 & 0 & 0 & 1 & 1 & 1 & 0 & 0 & 0 & 0 & 0 \\
\hline L. raisae & 0 & 0 & 2 & 0 & 0 & 1 & 0 & 0 & 0 & 0 & 1 & 0 & 0 & 2 & 1 & 4 \\
\hline M. lauensis & 2 & 0 & 3 & 8 & 4 & 1 & 3 & 0 & 14 & 31 & 49 & 76 & 2 & 504 & 50 & 137 \\
\hline Paralvinella & 0 & 3 & 0 & 5 & 0 & 0 & 26 & 0 & 0 & 0 & 0 & 0 & 0 & 0 & 0 & 0 \\
\hline P. hirtella & 0 & 0 & 0 & 0 & 0 & 0 & 0 & 0 & 0 & 1 & 4 & 0 & 0 & 16 & 1 & 0 \\
\hline Phymorynchus sp. & 0 & 0 & 0 & 0 & 0 & 0 & 0 & 0 & 0 & 0 & 0 & 0 & 0 & 1 & 0 & 0 \\
\hline Shrimp & 401 & 597 & 363 & 44 & 346 & 89 & 0 & 390 & 142 & 33 & 620 & 136 & 2 & 358 & 3 & 141 \\
\hline T. branchiata & 0 & 0 & 0 & 0 & 1 & 0 & 0 & 0 & 1 & 0 & 0 & 1 & 0 & 0 & 1 & 0 \\
\hline Vulcanolepas sp. & 2 & 0 & 0 & 0 & 0 & 0 & 0 & 0 & 0 & 0 & 0 & 15 & 0 & 0 & 0 & 0 \\
\hline Zoarcidae & 0 & 0 & 0 & 0 & 2 & 0 & 1 & 0 & 0 & 2 & 0 & 0 & 0 & 8 & 2 & 0 \\
\hline
\end{tabular}

were equal or greater than the global $R$ for overall percent cover, global $R=0.375, p=0.003$ and only 2 of 999 permuted statistics were greater than or equal to global $R$ for relative percent covers). Based on these results and the fact that edifice and lava sites did not cluster separately, we conclude that in terms of the conspicuous faunal groups that constitute most of the biomass of ELSC/VFR vent communities, edifice communities are extensions of the lava communities in the surrounding areas.

Although the lava and edifice assessment sites were similar with respect to the aggregated fauna they host, cluster analyses did detect differences in the solitary faunal communities between the two types of substrata (Fig. 7) and this could be due to the fact 


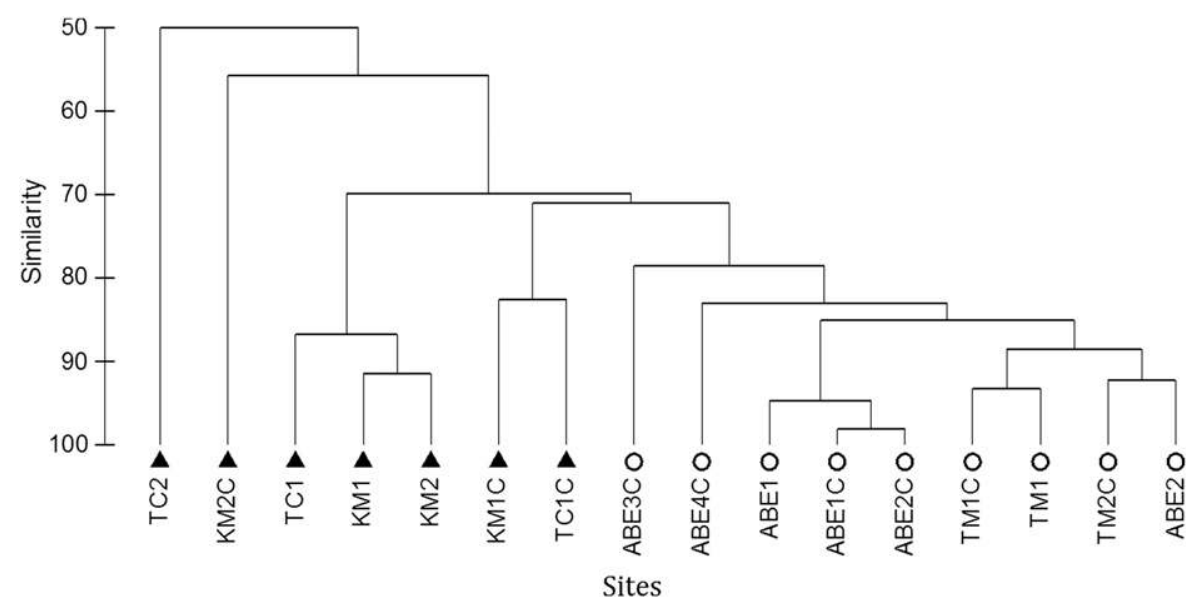

Fig. 5. Average linkage Bray-Curtis similarity for all sites based on overall percent cover of aggregated fauna (fourth root transformed). Circles represent southern sites and triangles represent northern sites.

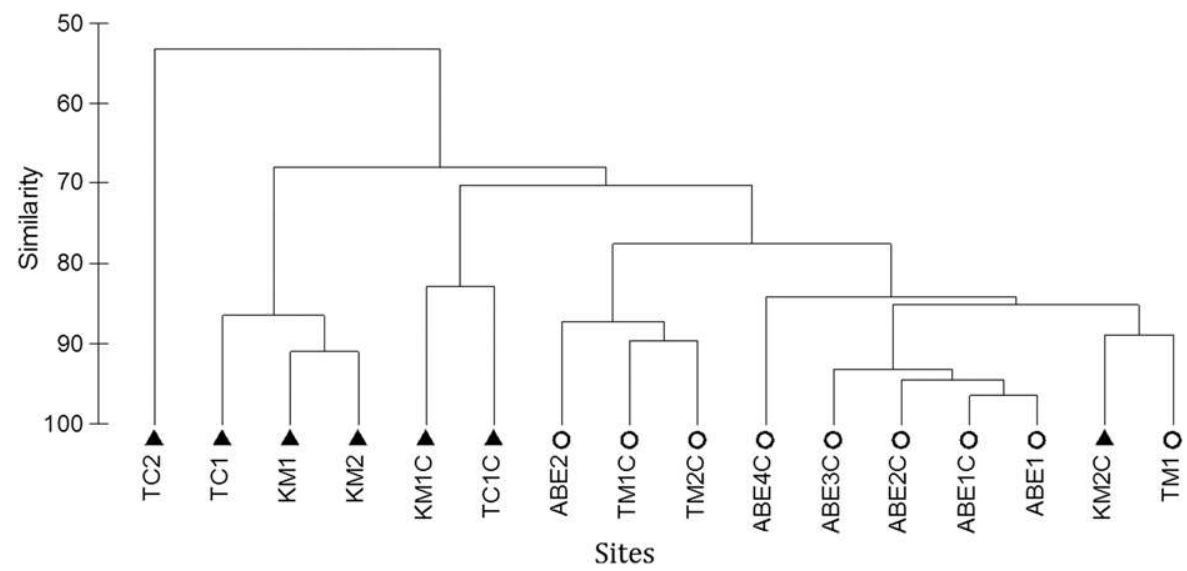

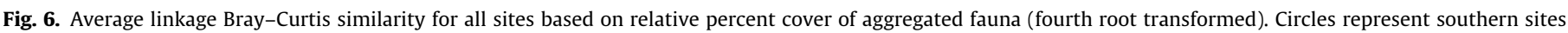
and triangles represent northern sites.

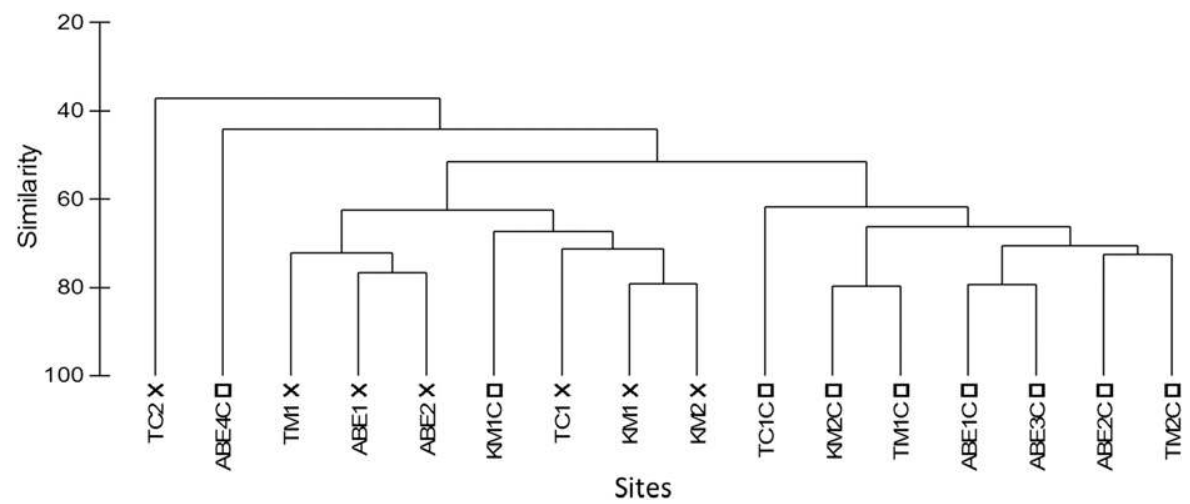

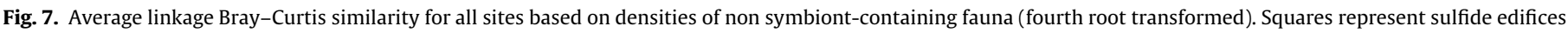
and crosses represent lava assessment sites.

that edifices host two distinct types of habitats. The numbers and densities of all solitary faunal groups are presented in Tables 3 and 4 . The KM1C edifice grouped with the lava assessment sites based on Bray-Curtis dissimilarity matrices of the solitary/mobile fauna communities and TC2 and ABE4C grouped separately from all the sites. TC2 was hypothesized to be a lava site in an early successional stage (Podowski et al., 2010) and about half of ABE4C is comprised of the white substrate that is likely anhydrite. Nonetheless, ANOSIM supported the difference between the communities on edifices and lavas (global $R=0.519$ at 0.001 significance and 0 out of 999 permutations being equal to or greater than the global $R$ ).

The presence and absence of certain faunal groups on either lavas or edifices and the differences in densities of other faunal groups between lavas and edifices could account for the clustering of sites based on type of substrate (lavas vs. edifices) for solitary fauna. Paralvinellid worms and $B$. segonzaci polynoids that were almost exclusively observed on the white, hot patches on edifices were not visible at any lava assessment site (Table 3). In addition to the species occupying the white, hot patches on 
edifices, there were a few other notable differences in the occurrence of the mobile and solitary fauna found on edifices and lavas. Some groups that were never observed in areas directly exposed to diffuse flow, such as brisingid sea stars and sponges, were documented in the lava community assessment sites but never seen on the active edifices in this study (Table 3 ). However, it should be noted that we have observed these groups on inactive edifices in the region. The large crab Paralomis hirtella was not observed at any sulfide edifice assessment site, although it is often present, albeit in low numbers, in areas of lava communities with low levels of exposure to hydrothermal flow (Podowski et al., 2010). Other fauna were present in both lava and edifice communities, but in quite different densities. For example, shrimp were generally found in higher densities on edifices than in lava communities while anemones, which were often abundant in lava communities (Podowski et al., 2010), were only present in low densities on edifices. The anemones found on edifices were restricted largely to the bases of the structures, where venting appears to be quite low. The sulfide assessment site KM1C, which clustered with the lava sites, was a large edifice with most of the symbiont-containing faunal biomass represented by mussels clustered at the top (about $15 \mathrm{~m}$ above the sea floor). This edifice site was also the only one to harbor the holothurian C. hydrothermica, which was present on most lava assessment sites associated with areas of low exposure to vent fluid. Additionally, a single anemone was present at the top of this edifice, which also harbored much lower densities of shrimp than most other edifices (Table 4).

The grouping of the least active edifice used in this study (KM1C) with lava communities and the observations of peripheral fauna on inactive edifices suggest that the differences in solitary faunal communities observed between edifice and lava sites are due to differences in successional stages. Only active edifices were used in this study and therefore we likely limited our study to edifices in early and mid-successional stages, while later successional stages are represented on inactive edifices. As an edifice ages and becomes less active, the community will shift from being dominated by symbiont-containing fauna (which require exposure to moderate sulfide levels, Henry et al., 2008) and heat tolerant associates to peripheral fauna that do not directly utilize vent fluid, nor have the tolerances to exploit bacteria growing in areas exposed to vent fluid. Lava communities relatively distant from sources of venting host peripheral fauna (Kim and Hammerstrom, 2012) and likely parallel communities on inactive edifices.
Mobile, solitary fauna that occurred on both edifices and lavas occupied similar microhabitats, with similar associations to the symbiont-containing fauna. Podowski et al. (2010) found that on lavas, the snail $E$. desbruyeresi and the squat lobster $M$. lauensis were present in areas exposed to very dilute or no hydrothermal flow and both were rarely found directly associated with symbiont-containing fauna. Although the numbers and densities of these species on sulfide edifices were too small to carry out similar chi-square analyses, the same trend was observed on edifices. Only $28 \%$ of all recorded individuals of $E$. desbruyeresi and $31 \%$ of individuals of $M$. lauensis were on or within $5 \mathrm{~cm}$ of aggregations of the symbiont-containing molluscs, typically a lone individual of $I$. nautilei or B. brevior. No individual of either of these species was ever found on or within $5 \mathrm{~cm}$ of Alviniconcha spp. Additionally, E. desbruyeresi was only present at the bases of edifices. $M$. lauensis also exhibited a preference for edifice bases, but were not found exclusively there (26 out of 35 individuals across all sulfide edifice assessment sites were at the bases of edifice structures).

The striking similarities between most edifice and lava communities on the ELSC/VFR are quite remarkable for hydrothermal vent systems. On the Juan de Fuca Ridge (JdFR) in the NE Pacific, several different edifice-specific communities dominate the biomass on sulfide edifices (Sarrazin and Juniper, 1999). These communities are dominated either by paralvinellid worms or the vestimentiferan Ridgeia piscesae. Though $R$. piscesae is also abundant on lavas, the morphotypes present on edifices are quite distinct from the individuals present in lavas, and the communities associated with the edifice $R$. piscesae are different from those associated with the lava morphotype of R. piscesae (Bergquist et al., 2007; Govenar et al., 2002; Sarrazin and Juniper, 1999). Alvinellid worm communities dominate active edifices on the East Pacific Rise (Chevaldonne and Jollivet, 1993; Fustec et al., 1988; Juniper and Martineu, 1995), though vestimentiferans such as Riftia pachyptila and Tevnia jerichonana are occasionally present on edifices (Shank et al., 1998). On the Mid Atlantic Ridge (MAR), the upper reaches of edifices can be dominated by massive swarms of Caridean shrimp. (Copley et al., 2007; Desbruyères et al., 2000, 2001; Gebruk et al., 2000; Rona et al., 1986). Though ELSC/VFR edifices contain unique communities not found on lavas, these communities are confined to relatively small areas and the total biomass represented in these communities is quite low in comparison to that in areas occupied by the symbiontcontaining molluscs.

Table 4

Densities of solitary fauna (individuals per $\mathrm{m}^{2}$ ) on all sulfide edifice and lava assessment sites.

\begin{tabular}{|c|c|c|c|c|c|c|c|c|c|c|c|c|c|c|c|c|}
\hline \multirow[t]{2}{*}{ Taxa } & \multicolumn{9}{|c|}{ Sulfide edifice assessment sites } & \multicolumn{7}{|c|}{ Lava assessment sites } \\
\hline & KM1C & KM2C & TC1C & ABE1C & ABE2C & ABE3C & ABE4C & TM1C & TM2C & KM1 & KM2 & TC1 & TC2 & ABE1 & ABE2 & TM1 \\
\hline Anemones & 0.5 & 0.0 & 0.0 & 8.0 & 1.0 & 3.5 & 2.1 & 0.0 & 0.0 & 7.7 & 11.1 & 74.9 & 0.3 & 0.0 & 9.8 & 1.3 \\
\hline Austinograea spp. & 1.7 & 3.3 & 0.0 & 3.1 & 7.3 & 3.5 & 23.3 & 2.4 & 1.7 & 3.6 & 3.5 & 3.0 & 2.2 & 4.1 & 4.0 & 3.0 \\
\hline B. segonzaci & 0.0 & 7.6 & 0.3 & 32.8 & 18.5 & 28.1 & 95.1 & 3.4 & 1.7 & 0.0 & 0.0 & 0.0 & 0.0 & 0.0 & 0.0 & 0.0 \\
\hline B. sp. nov. & 0.0 & 0.0 & 0.0 & 0.0 & 0.0 & 0.0 & 0.0 & 0.0 & 0.0 & 0.0 & 0.0 & 0.0 & 0.0 & 0.0 & 0.0 & 0.0 \\
\hline B. trifurcus & 0.0 & 0.0 & 0.0 & 0.0 & 0.0 & 0.0 & 0.0 & 0.0 & 0.0 & 0.0 & 0.0 & 0.0 & 0.0 & 0.0 & 0.0 & 0.0 \\
\hline C. hydrothermica & 1.0 & 0.0 & 0.0 & 0.0 & 0.0 & 0.0 & 0.0 & 0.0 & 0.0 & 0.4 & 0.3 & 0.4 & 0.0 & 0.0 & 0.0 & 0.0 \\
\hline Cladorhizid sponge & 0.0 & 0.0 & 0.0 & 0.0 & 0.0 & 0.0 & 0.0 & 0.0 & 0.0 & 0.0 & 0.1 & 0.0 & 0.0 & 0.0 & 0.0 & 0.0 \\
\hline E. desbruyeresi & 0.1 & 0.0 & 0.2 & 0.4 & 0.3 & 2.6 & 2.1 & 1.7 & 0.3 & 0.0 & 0.4 & 0.1 & 0.0 & 3.5 & 1.5 & 0.2 \\
\hline Harmothoe sp. & 0.2 & 0.0 & 0.0 & 0.0 & 0.1 & 0.0 & 0.0 & 0.0 & 0.0 & 0.0 & 0.0 & 0.0 & 0.0 & 0.0 & 0.0 & 0.0 \\
\hline L. raisae & 0.0 & 0.0 & 0.1 & 0.0 & 0.0 & 0.0 & 0.0 & 0.0 & 0.0 & 0.0 & 0.0 & 0.0 & 0.0 & 0.1 & 0.0 & 0.1 \\
\hline M. lauensis & 0.1 & 0.0 & 0.5 & 3.5 & 0.6 & 0.9 & 6.3 & 0.0 & 4.0 & 1.4 & 1.1 & 2.3 & 0.1 & 12.1 & 9.1 & 4.3 \\
\hline Paralvinella & 0.0 & 0.4 & 0.0 & 2.2 & 0.0 & 0.0 & 55.0 & 0.0 & 0.0 & 0.0 & 0.0 & 0.0 & 0.0 & 0.0 & 0.0 & 0.0 \\
\hline P. hirtella & 0.0 & 0.0 & 0.0 & 0.0 & 0.0 & 0.0 & 0.0 & 0.0 & 0.0 & 0.0 & 0.1 & 0.0 & 0.0 & 0.4 & 0.2 & 0.0 \\
\hline Phymorynchus sp. & 0.0 & 0.0 & 0.0 & 0.0 & 0.0 & 0.0 & 0.0 & 0.0 & 0.0 & 0.0 & 0.0 & 0.0 & 0.0 & 0.0 & 0.0 & 0.0 \\
\hline Shrimp & 11.2 & 71.9 & 62.3 & 19.5 & 51.7 & 78.3 & 0.0 & 131.3 & 40.7 & 1.5 & 13.7 & 4.0 & 0.0 & 8.6 & 0.5 & 4.4 \\
\hline T. branchiata & 0.0 & 0.0 & 0.0 & 0.0 & 0.0 & 0.0 & 0.0 & 0.0 & 0.0 & 0.0 & 0.0 & 0.0 & 0.0 & 0.0 & 0.0 & 0.0 \\
\hline Vulcanolepas sp. & 0.1 & 0.0 & 0.0 & 0.0 & 0.0 & 0.0 & 0.0 & 0.0 & 0.0 & 0.0 & 0.0 & 0.4 & 0.0 & 0.0 & 0.0 & 0.0 \\
\hline Zoarcidae & 0.0 & 0.0 & 0.0 & 0.0 & 0.3 & 0.0 & 2.1 & 0.0 & 0.0 & 0.1 & 0.0 & 0.0 & 0.0 & 0.2 & 0.4 & 0.0 \\
\hline
\end{tabular}




\subsection{Habitats of the dominant symbiont-containing molluscs}

Alviniconcha spp. was found in the warmest water $\left(7^{\circ} \mathrm{C}\right.$ above ambient average) on edifices among the dominant symbiontcontaining molluscs, I. nautilei in intermediate temperatures (3.3 ${ }^{\circ} \mathrm{C}$ above ambient average) and B. brevior in the coldest water $\left(1.7^{\circ} \mathrm{C}\right.$ above ambient average). The temperatures associated with each symbiont-containing faunal group was significantly different from the others ( $p=0.0003$ for Alviniconcha spp. and I. nautilei and $p=0.0007$ for $I$. nautilei and $B$. brevior). Though the thermal characteristics of the edifice habitats of $I$. nautilei and B. brevior were significantly different, the ranges overlapped substantially, and the averages differed by only a few degrees. Only Alviniconcha spp. occupied a habitat that was significantly different chemically from the other symbiont-containing molluscs. The sulfide concentration is significantly higher and oxygen lower among Alviniconcha spp. than I. nautilei ( $p<0.005$ for both) and B. brevior $(p<0.001$ for both, Fig. 8B). Neither sulfide nor oxygen levels were significantly different between $I$. nautilei and $B$. brevior edifice habitats.

To better understand the niches of the dominant symbiontcontaining molluscs, we compared the thermal and chemical habitats on edifices to the thermal and chemical habitats on lavas reported by Podowski et al. (2010). Although the same general pattern of a thermal continuum from Alviniconcha spp. in the warmest water to $B$. brevior in the coolest water was found in both habitats, the sulfide and oxygen levels in their habitats were not significantly different on sulfide edifices but were on lavas. Another difference between the habitats occupied by each of the groups on lavas and sulfides was the range of thermal and chemical conditions associated with each mollusc: they occupied a narrower range of chemical and thermal conditions on edifices than the same species on lavas. The highest temperatures and sulfide levels measured among the symbiont-containing molluscs on lavas were higher than on edifices (Fig. 8). Although we did not detect any significant differences between the chemical habitats occupied by any of the dominant symbiont-containing molluscs on edifices and lavas, the average temperatures measured around both $I$. nautilei and $B$. brevior on edifices were significantly less than on lavas ( $p<0.001$ for both). There was a similar trend for Alviniconcha spp.: the highest mean temperature measured among Alviniconcha spp. on edifices was $10.6^{\circ} \mathrm{C}$, while temperatures above $20^{\circ} \mathrm{C}$ were often measured among Alviniconcha spp. on lavas (Podowski et al., 2010, Fig. 3).

Based on their realized distributions on lavas (Podowski et al., 2010) and tolerances measured in laboratory studies (Henry et al., 2008), we conclude that all three groups of symbiont-containing molluscs were exposed to chemical and thermal conditions well below their tolerance levels on edifices. For example, in laboratory experiments, stress is apparent in $B$. brevior at $20^{\circ} \mathrm{C}$, but the highest measured temperature among $B$. brevior was only $10.5^{\circ} \mathrm{C}$ on sulfide edifice assessment sites. Similarly, the highest mean temperature among the snails on edifices was $18.3^{\circ} \mathrm{C}$, which is well below $45^{\circ} \mathrm{C}$, the temperature at which these snails show signs of heat stress (Henry et al., 2008). Furthermore, based on the laboratory data, none of the dominant symbiont-containing molluscs were in areas where chemoautotrophy can be maximized. The sulfide levels at which peak metabolite uptake rates were measured in Alviniconcha spp. ( $\sim 400 \mu \mathrm{mol}$, Henry et al., 2008) were not found in-situ at temperatures within the thermal tolerances of this group of snails (Podowski et al., 2010). However, these snails were often found adjacent to high-temperature areas of very active venting $\left(>100{ }^{\circ} \mathrm{C}\right)$ and in one case, directly above such an area. Sulfide concentrations in these areas are likely to also be high, and the proximity of Alviniconcha spp. to these areas suggests that being close to sources of active venting could
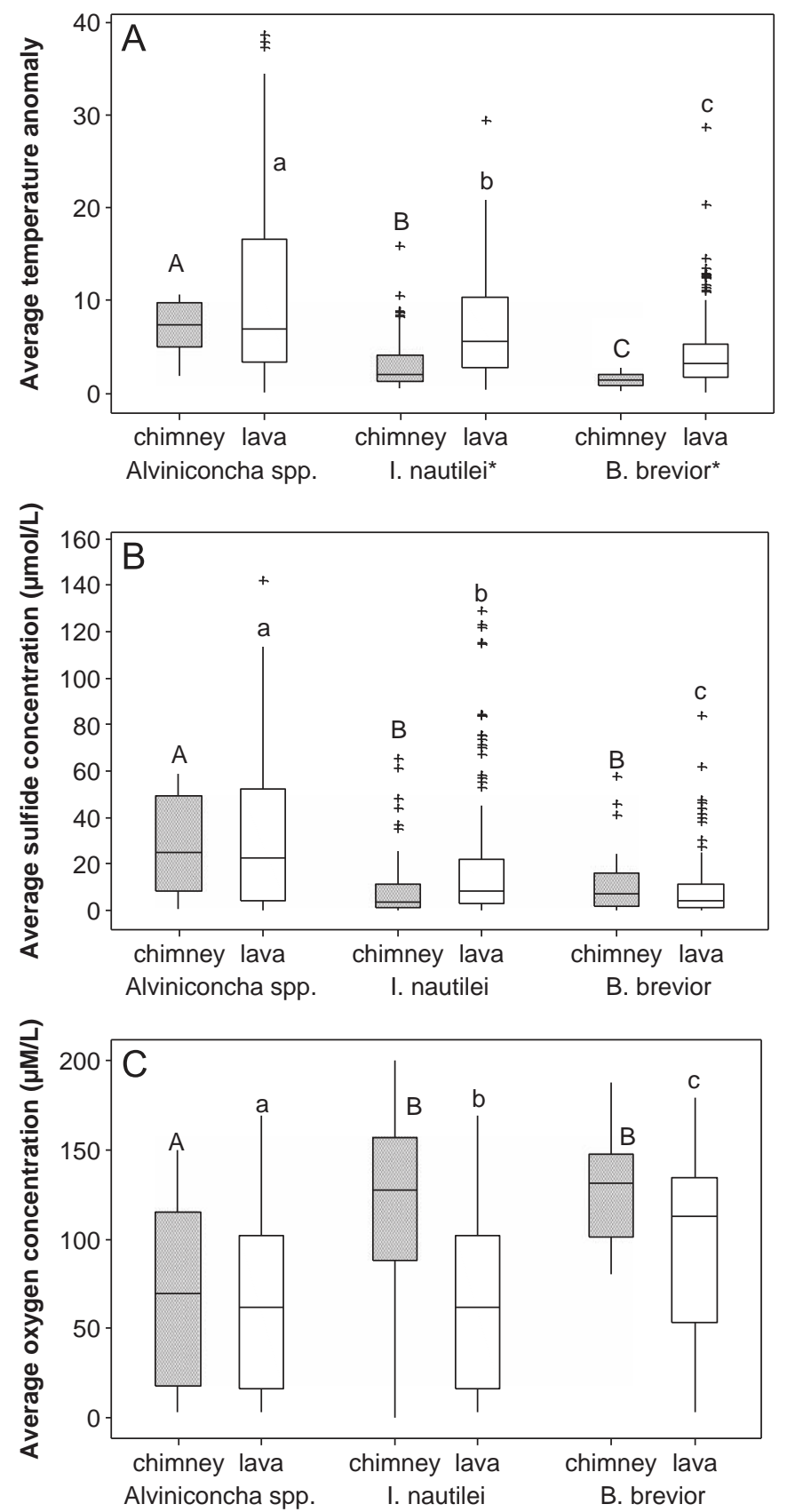

Fig. 8. Box plots of average temperature anomaly, sulfide and oxygen concentration associated with the three groups of symbiont-containing fauna. The box represents the interquartile range and the whiskers represent the upper and lower limits (defined as the value at $Q 3+1.5(Q 3-Q 1)$ for upper limit and $Q 1-1.5(Q 3-Q 1)$ for lower limit). Asterisks above the whiskers represent values that are greater than the value at the upper limit. An asterisk next to the name of a mollusk group indicates a significant difference between edifices and lavas for that particular group (Bonferroni correction $p=0.00556$ ). Capital letters indicate comparisons between the three groups at edifices while lowercase letters represent comparisons between the three groups at lava sites. Same letters represent no significant difference and different letters indicate significant differences (Bonferroni correction $p=0.01667$ for temperature and $p=0.0083$ for sulfide and oxygen).

occasionally provide access to much higher levels of sulfide than we measured.

Similarly, in terms of both temperature and sulfide concentrations, neither I. nautilei nor B. brevior were located in areas with conditions that would support maximal rates of chemoautotrophy for those species. None of the mean sulfide concentrations 
measured among I. nautilei and B. brevior at the sulfide edifice assessment sites were within the range of sulfide levels at which peak metabolite uptake rates occur for these two species ( $\sim 100 \mu \mathrm{mol}$ for $I$. nautilei and $200 \mu \mathrm{mol}$ for $B$. brevior, Henry et al., 2008). Only eight temperature measurements of 50 among I. nautilei were within the range of temperatures that supported maximal rates of chemoautotrophy in shipboard experiments (10-20 ${ }^{\circ} \mathrm{C}$, Henry et al., 2008). Maximal rates of chemoautotrophy was determined to occur between 10 and $15{ }^{\circ} \mathrm{C}$ in $B$. brevior (Henry et al., 2008); however, the highest temperature measurement associated with this species on edifices was only $8{ }^{\circ} \mathrm{C}$.

Together, our measurements indicate that the temperatures and sulfide levels in areas inhabited by the dominant symbiontcontaining molluscs on edifices are less than those that support maximal rates of chemoautotrophy and well below their thermochemical tolerances. Sulfide edifices also host areas, such as the white patches discussed above, where temperatures above $50{ }^{\circ} \mathrm{C}$ and often $100{ }^{\circ} \mathrm{C}$ were documented, which is beyond the thermal limits of the dominant symbiont-containing molluscs. Alviniconcha spp. can be present very near these areas. This may reflect extreme temporal variability in exposure to vent fluid on sulfide edifices that we missed with our survey. The rapid rise and dissipation of hot vent fluid from point sources of active venting results in steep gradients and limited areas appropriate for chemoautotrophy by the dominant symbiont-containing molluscs. As a result, large bare areas as well as dense patches of animals exist on edifice faces in different locations.

The similarity between habitats occupied by the dominant symbiont-containing molluscs on edifices, and the fact that none of them occupy areas where they could maximize chemoautotrophy, implies that either biological interactions between species or species-specific characteristics other than physiological requirements or tolerances are also contributing significantly to their realized distribution patterns on edifices. The habitat of Alviniconcha spp. on edifices is thermally and chemically distinct from the habitats of both $I$. nautilei and B. brevior, but not significantly distinct from its habitat on lavas. Additionally, the edifice habitat of Alviniconcha spp. is within the ranges for maximum chemoautotrophy for both I. nautilei and B. brevior. Therefore, it is likely that Alviniconcha spp. is the superior competitor, enabling it to occupy the most productive habitable areas on edifices. Adult Alviniconcha spp. appear to be the most mobile of the three dominant symbiontcontaining molluscs (Erin L. Becker, pers. comm.), and this trait could facilitate competition for the most productive areas as they become available on edifice surfaces. Little is known about dispersal or recruitment dynamics of the symbiont-containing molluscs on the ELSC/VFR, but these could also play a role in conferring an advantage to Alviniconcha spp. over the other molluscs in their ability to reach and occupy the most productive areas on edifices. We have observed large, potentially long-lived individuals of Alviniconcha spp. on edifices, but whether these animals have been dominating a particular location since their juvenile stages or whether they have moved around on an edifice as the structure changed over time is unknown.

Mobility could be an important factor with respect to the competition between I. nautilei and B. brevior as well. I. nautilei occupies distinctly hotter locations than $B$. brevior and appears to be more mobile than mussels. Therefore, I. nautilei could be more adept than $B$. brevior at occupying new locations as they become available.

The fine-scale partitioning discussed above could contribute to the notable lack of the mixed aggregations of $I$. nautilei and $B$. brevior on edifices that are quite abundant on lava assessment sites. Podowski et al. (2010) hypothesized that mixed aggregations of these two species occur when conditions are particularly stressful in terms of heat for mussels, resulting in successful invasion by I. nautilei. Our data support this hypothesis. Since areas occupied by the two species were not stressful for mussels because conditions were below their thermal limits, distinct clusters of either I. nautilei or B. brevior occur on edifices based on their differential mobility and ability to occupy productive areas. Alternatively, the lack of mixed aggregations could also be due to the vertical nature of edifices. Mixed aggregations tend to occur where the fauna was present in multiple layers of animals, but monolayers dominated on edifices with substrate clearly visible between individuals. On edifices, stacking on top of one another would be precarious. Furthermore on lavas rising vent fluid percolates through aggregations of animals that can be many layers deep (Podowski et al., 2010) while on edifices, fluid flows upward along the side of an edifice.

\section{Conclusion}

Edifices on the ELSC/VFR host two distinct types of communities. One type, which covers the majority of edifice surfaces, is very similar to lava communities. Therefore, overall, ELSC/VFR edifice communities are largely extensions of the surrounding lava communities. Within this community, areas with conditions that would support peak rates of chemoautotrophy for any species are relatively rare, and most of the dominant symbiontcontaining molluscs do not occupy optimal habitats most of the time. As a result, biological interactions are likely to be very important in determining the observed distributions of animals on edifices.

The second type of edifice community is present on small portions of edifices that are possibly newly formed anhydrite shells, representing a hot, early phase in the formation of a sulfide structure. This community is characterized by a very different microhabitat that is favored by the polynoid, $B$. segonzaci and paralvinellid worms, and occupied by shrimp and Bythograeid crabs. This habitat is actively avoided by the dominant symbiontcontaining molluscs. Our limited measurements in these areas indicate high temperatures and therefore tolerances for heat, sulfide and anoxia likely determine which species can survive in this habitat. Animals that are adapted to handle the stressful conditions in this microhabitat could be utilizing free-living chemoautotrophic bacteria as a food source without competition from limpets that appear to prefer dominant symbiont-containing mollusc aggregations and cooler areas of edifices. Polynoids are predators and $B$. segonzaci may specialize in feeding on the fauna found in this habitat. Interactions among the different groups of solitary fauna as well as interactions between the dominant symbiont-containing molluscs and solitary fauna are areas for further research that could further elucidate the drivers of realized distributions of animals on edifice structures.

\section{Acknowledgments}

This project was funded by National Science Foundation (NSF) grants OCE02-40985 and OCE07-32333 to C.R.F. and NSF OCE0240896 and OCE-0732439 to G.W.L. We thank the crews of the $\mathrm{R} / \mathrm{V}$ Melville and the ROV Jason II for their expertise, without whom this work would not have been possible. We thank Mustafa Yücel and Tommy Moore for shipboard analysis of voltammetry data. We also thank Eric Post and Alex Klippel for advice on methods and Katriona Shea and three anonymous reviewers for comments and suggestions on the manuscript.

The funding sources did not play a role in study design, collection, analysis, interpretation of data, writing of the report or in the decision to submit the paper for publication. 


\section{References}

Baker, E.T., Resing, J.A., Walker, S.L., Martinez, F., Taylor, B., Nakamura, K., 2006. Abundant hydrothermal venting along melt-rich and melt-free ridge segments in the Lau back-arc basin. Geophys. Res. Lett. 33 (7)

Beinart, R.A., Sanders, J.G., Faure, B., Sylva, S.P., Lee, R.W., Becker, E.L., Gartman, A., Luther, G.W.III, Seewald, J.S., Fisher, C.R., Girguis P.R., 2012. Endosymbiont type drives regional-scale habitat partitioning by hydrothermal vent symbioses. PNAS 109 (47), E3241-E3250.

Bergquist, D.C., Eckner, J.T., Urcuyo, I.A., Cordes, E.E., Hourdez, S., Macko, S.A. Fisher, C.R., 2007. Using stable isotopes and quantitative community characteristics to determine a local hydrothermal vent food web. Mar. Ecol.-Prog. Ser. 330, 49-65.

Both, R., Crook, K., Taylor, B., Brogan, S., Chappell, B., Frankel, E., Liu, L., Sinton, J. Tiffin, D., 1986. Hydrothermal chimneys and associated fauna in the Manus back-arc basin, Papua New Guinea. EOS 67 (21), 489-490.

Chevaldonne, P., Jollivet, D., 1993. Videoscopic study of deep-sea hydrothermal vent alvinellid polychaete populations-biomass estimation and behavior. Mar. Ecol.-Prog. Ser. 95 (3), 251-262.

Clarke, K.R., 1993. Nonparametric multivariate analyses of changes in community structure. Aust. J. Ecol. 18 (1), 117-143.

Clarke, K.R., Warwick, R.M., 2001. Change in Marine Communities: An Approach to Statistical Analysis and Interpretation. Plymouth Marine Laboratory, Plymouth, UK

Copley, J.T.P., Tyler, P.A., Murton, B.J., Van Dover, C.L., 1997. Spatial and interannual variation in the faunal distribution at Broken Spur vent field $\left(29^{\circ} \mathrm{N}\right.$, Mid Atlantic Ridge). Mar. Biol. 129 (4), 723-733.

Copley, J.T.P., Tyler, P.A., Van Dover, C.L., Schultz, A., Dickson, P., Singh, S. Sulanowska, M., 1999. Subannual temporal variation in faunal distributions a the TAG hydrothermal mound (26 N, Mid-Atlantic Ridge). Mar. Ecol. 20 (3-4), 291-306.

Copley, J.T.P., Jorgensen, P.B.K., Sohn, R.A., 2007. Assessment of decadal-scale ecological change at a deep Mid-Atlantic hydrothermal vent and reproductive time-series in the shrimp Rimicaris exoculata. J. Mar. Biol. Assoc. UK 87 (04) 859.

Cuvelier, D., Sarradin, P.-M., Sarrazin, J., Colaço, A., Copley, J.T., Desbruyères, D. Glover, A.G., Santos, R.S., Tyler, P.A., 2011. Hydrothermal faunal assemblages and habitat characterisation at the Eiffel Tower edifice (Lucky Strike, MidAtlantic Ridge). Mar. Ecol. 32 (2), 243-255

Desbruyères, D., Alayse-Danet, A.-M., Ohta, S., cruises, T.S.p.o.B.a.S., 1994. Deepsea hydrothermal communities in Southwestern Pacific back-arc basins (the North Fiji and Lau Basins): Composition, microdistribution and food webs Mar. Geol. 116, 227-242.

Desbruyères, D., Almeida, A., Biscoito, M., Comtet, T., Khripounoff, A., Le Bris, N., Sarradin, P.M., Segonzac, M., 2000. A review of the distribution of hydrothermal vent communities along the northern Mid-Atlantic Ridge: dispersal vs. environmental controls. Hydrobiologia 440 (1-3), 201-216.

Desbruyères, D., Biscoito, M., Caprais, J.C., Colaco, A., Comtet, T., Crassous, P., Fouquet, Y., Khripounoff, A., Le Bris, N., Olu, K., Riso, R., Sarradin, P.M. Segonzac, M., Vangriesheim, A., 2001. Variations in deep-sea hydrotherma vent communities on the Mid-Atlantic Ridge near the Azores plateau. DeepSea Res. Part I-Oceanogr. Res. Pap. 48 (5), 1325-1346.

Dilly, G.F., Young, C.R., Lane, W.S., Pangilinan, J., Girguis, P.R., 2012. Exploring the limit of metazoan thermal tolerance via comparative proteomics: thermally induced changes in protein abundance by two hydrothermal vent polychaetes. Proc. R. Soc. B-Biol. Sci. 279 (1741), 3347-3356.

Dunn, O.J., 1961. Multiple comparisons among means. J. Am. Stat. Assoc. 56, $52-64$

Fabri, M.-C., Bargain, A., Briand, P., Gebruk, A., Fouquet, Y., Morineaux, M. Desbruyeres, D., 2011. The hydrothermal vent community of a new deep-sea field, Ashadze-1, $12^{\circ} 58^{\prime} \mathrm{N}$ on the Mid-Atlantic Ridge. J. Mar. Biol. Assoc. UK 91 (01), 1-13.

Ferrini, V.L., Tivey, M.K., Carbotte, S.M., Martinez, F., Roman, C., 2008. Variable morphologic expression of volcanic, tectonic, and hydrothermal processes at six hydrothermal vent fields in the Lau back-arc basin. Geochem. Geophys. Geosyst. 9, 7 .

Fisher, C.R., 1998. Temperature and sulphide tolerance of hydrothermal vent fauna. Cah. Biol. Mar. 39 (3-4), 283-286.

Fouquet, Y., von Stackelber, U., Charlou, J.L., Donval, J.P., Erzinger, J., Foucher, J.P., Herzing, P., Mühe, R., Soakai, S., Wiedicke, M., Whitechurch, H., 1991a. Hydrothermal activity and metallogenesis in the Lau back-arc basin. Nature 349, 778-781

Fouquet, Y., von Stackelber, U., Charlou, J.L., Donval, J.P., Foucher, J.P., Erzinger, J. Herzing, P., Mühe, R., Wiedicke, M., Soakai, S., Whitechurch, H., 1991b. Hydrothermal activity in the Lau Back-arc basin: Sulfides and water chemistry. Geology 19, 303-306.
Fustec, A., Desbruyeres, D., Laubier, L., 1988. Estimation de la biomasse des peuplements associés aux sources hydrothermales profondes de la dorsale du Pacifique oriental à $13^{\circ} \mathrm{N}$. Oceanol. Acta 8, 15-22.

Gartman, A., Yücel, M., Madison, A.S., Chu, D.W., Ma, S., Janzen, C.P., Becker, E.L., Beinart, R.A., Girguis, P.R., Luther III, G.W., 2011. Sulfide oxidation across diffuse flow zones of hydrothermal vents. Aquat. Geochem. 17, 583-601.

Gebruk, A.V., Southward, E.C., Kennedy, H., Southward, A.J., 2000. Food sources, behaviour, and distribution of hydrothermal vent shrimps at the Mid-Atlantic Ridge. J. Mar. Biol. Assoc. UK 80 (3), 485-499.

Girguis, P.R., Lee, R.W., 2006. Thermal preference and tolerance of alvinellids. Science 312 (5771) 231

Govenar, B.W., Bergquist, D.C., Urcuyo, I.A., Eckner, J.T., Fisher, C.R., 2002 Three Ridgeia piscesae assemblages from a single Juan de Fuca Ridge sulphide edifice: structurally different and functionally similar. Cah. Biol. Mar. 43 (3-4), 247-252.

Govenar, B., 2010. Shaping vent and seep communities: habitat provision and modification by foundation species. In: Kiel, S. (Ed.), The Vent and Seep Biota. Springer, Netherlands, pp. 403-432.

Graham, U.M., Bluth, G.J., Ohmoto, H., 1988. Sulfide sulfate chimneys on the East Pacific Rise, 11-degrees-n and 13-degrees-n latitudes.1. Mineralogy and paragenesis. Can. Mineral. 26, 487-504.

Harmsen, H.J.M., Prieur, D., Jeanthon, C., 1997. Distribution of microorganisms in deep-sea hydrothermal vent chimneys investigated by whole-cell hybridization and enrichment culture of thermophilic subpopulations. Appl. Environ. Microbiol. 63 (7), 2876-2883.

Haymon, R.M., 1983. Growth history of hydrothermal black smoker chimneys. Nature 301 (5902), 695-698.

Henry, M.S., Childress, J.J., Figueroa, D., 2008. Metabolic rates and thermal tolerances of chemoautotrophic symbioses from Lau Basin hydrothermal vents and their implications for species distributions. Deep Sea Res. Part I: Oceanogr. Res. Pap. 55 (5), 679-695.

Jannasch, H.W., 1995. Microbial interactions with hydrothermal fluids. Seafloor Hydrothermal Systems: Physical, Chemical, Biological, and Geological Interactions. AGU, Washington, DC 273-296.

Juniper, S.K., Martineu, P., 1995. Alvinellids and sulfides at hydrothermal vents of the Eastern Pacific - a review. Am. Zool. 35 (2), 174-185.

Kim, S., Hammerstrom, K., 2012. Hydrothermal vent community zonation along environmental gradients at the Lau back-arc spreading center. Deep-Sea Res. Part I-Oceanogr. Res. Pap. 62, 10-19.

Koski, R.A., Shanks, W.C., Bohrson, W.A., Oscarson, R.L., 1988. The composition of massive sulfide deposits from the sediment-covered floor of Escanaba trough, Gorda Ridge-implications for depositional processes. Can. Mineral. 26, 655-673.

Lee, R.W., 2003. Thermal tolerances of deep-sea hydrothermal vent animals from the Northeast Pacific. Biol. Bull. 205 (2), 98-101.

Lenihan, H.S., Mills, S.W., Mullineaux, L.S., Peterson, C.H., Fisher, C.R., Micheli, F., 2008. Biotic interactions at hydrothermal vents: Recruitment inhibition by the mussel Bathymodiolus thermophilus. Deep-Sea Res. Part I-Oceanogr. Res. Pap. 55 (12), 1707-1717

Levesque, C., Juniper, S.K., Marcus, J., 2003. Food resource partitioning and competition among alvinellid polychaetes of Juan de Fuca Ridge hydrothermal vents. Mar. Ecol. Prog. Ser. 246, 173

Luther, G.W., Rozan, T.F., Taillefert, M., Nuzzio, D.B., Di Meo, C., Shank, T.M., Lutz, R.A., Cary, S.C., 2001. Chemical speciation drives hydrothermal vent ecology. Nature 410 (6830), 813-816.

Luther III, G.W., Glazer, B.T., Ma, S., Trouwborst, R.E., Moore, T.S., Metzger, E., Kraiya, C., Waite, T.J., Druschel, G., Sundby, B., Taillefert, M., Nuzzio, D.B., Shank, T.M., Lewis, B.L., Brendel, P.J., 2008. Use of voltammetric solid-state (micro)electrodes for studying biogeochemical processes: laboratory measurements to real time measurements with an in situ electrochemical analyzer (ISEA). Mar. Chem. 108, 221-235

Luther III, G.W., Gartman, A., Yücel, M., Madison, A.S., Moore, T.S., Nees, H.A., Nuzzio, D.B., Sen, A., Lutz, R.A., Shank, T.M., Fisher., C.R., 2012. Chemistry, temperature, and faunal distributions at diffuse-flow hydrothermal vents: comparison of two geologically distinct ridge systems. Oceanography 25 (1), 234-245.

Micheli, F., Peterson, C.H., Mullineaux, L.S., Fisher, C.R., Mills, S.W., Sancho, G., Johnson, G.A. Lenihan, H.S., 2002. Predation structures communities at deepsea hydrothermal vents. Ecol. Monogr. 72 (3), 365-382.

Martinez, F., Taylor, B., Baker, E.T., Resing, J.A., Walker, S.L., 2006. Opposing trends in crustal thickness and spreading rate along the back-arc Eastern Lau Spreading Center: Implications for controls on ridge morphology, faulting, and hydrothermal activity. Earth Planet. Sci. Lett. 245 (3-4), 655-672.

Mottl, M.J., Seewald, J.S., Wheat, C.G., Tivey, M.K., Michael, P.J., Proskurowski, G., McCollom, T.M., Reeves, E., Sharkey, J., You, C.F., Chan, L.H., Pichler, T., 2011. Chemistry of hot springs along the Eastern Lau Spreading Center. Geochim. Cosmochim. Acta 75 (4), 1013-1038.

Mullaugh, K.M., Luther, G.W., Ma, S., Moore, T.S., Yucel, M., Becker, E.L., Podowski, E.L., Fisher, C.R., Trouwborst, R.E., Pierson, B.K., 2008. Voltammetric (micro)electrodes for the in situ study of $\mathrm{Fe}(2+)$ oxidation kinetics in hot springs and $\mathrm{S}_{2} \mathrm{O}_{3}^{2-}$ production at hydrothermal vents. Electroanalysis 20 (3), 280-290.

Pearce, J.A., Ernewein, M., Bloomer, S.H., Parson, L.M., Murton, B.J., Johnson, L.E., 1994. Geochemistry of Lau Basin volcanic rocks: influence of ridge segmentation and arc proximity. In: Smellie, J.L. (Ed.), Volcanism Associated With Extension at Consuming Plate Margins. Geological Society Special Publications, pp. 53-75. 
Pizarro, O., Singh, H., 2003. Toward large-area mosaicing for underwater scientific applications. IEEE J. Oceanic Eng. 28 (4), 651-672.

Podowski, E.L., Ma, S., Luther, G.W., Wardrop, D., Fisher, C.R., 2010. Biotic and abiotic factors affecting distributions of megafauna in diffuse flow on andesite and basalt along the Eastern Lau Spreading Center, Tonga. Mar. Ecol. Prog. Ser. 418, 25-45.

Podowski, E.L., Moore, T.S., Zelnio, K.A., Luther, G.W., Fisher, C.R., 2009. Distribution of diffuse flow megafauna in two sites on the Eastern Lau Spreading Center, Tonga. Deep Sea Res. Part I: Oceanogr. Res. Pap. 56 (11), 2041-2056.

Rona, P.A., Klinkhammer, G., Nelsen, T.A., Trefry, J.H., Elderfield, H., 1986. Black smokers, massive sulfides and vent biota at the mid-atlantic ridge. Nature 321 (6065), 33-37.

Sarrazin, J., Juniper, S.K., 1999. Biological characteristics of a hydrothermal edifice mosiac community. Mar. Ecol. Prog. Ser. 185, 1-10.

Shank, T.M., Fornari, D.J., Von Damm, K.L., Lilley, M.D., Haymon, R.M., Lutz, R.A., 1998. Temporal and spatial patterns of biological community development at nascent deep-sea hydrothermal vents ( $9^{\circ} 50^{\prime} \mathrm{N}$, East Pacific Rise). Deep Sea Res. Part II: Top. Stud. Oceanogr. 45, 465-515.

Stein, J.L., Cary, S.C., Hessler, R.R., Ohta, S., Vetter, R.D., Childress, J.J., Felbeck, H. 1988. Chemoautotrophic symbiosis in a hydrothermal vent gastropod. Biol. Bull. 174, 373-378.

Takai, K., Nunoura, T., Ishibashi, J.I., Lupton, J., Suzuki, R., Hamasaki, H., Ueno, Y., Kawagucci, S., Gamo, T., Suzuki, Y., Hirayama, H., Horikoshi, K., 2008.
Variability in the microbial communities and hydrothermal fluid chemistry at the newly discovered Mariner hydrothermal field, southern Lau Basin. J. Geophys. Res.-Biogeosci. 113 (G2).

Taylor, B., Zellmer, K., Martinez, F., Goodliffe, A., 1996. Sea-floor spreading in the Lau back-arc basin. Earth Planet. Sci. Lett. 144 (1-2), 35-40.

Tivey, M.K., Delaney, J.R., 1986. Growth of large sulfide structures on the Endeavor segment of the Juan-de-Fuca Ridge. Earth Planet. Sci. Lett. 77 (3-4), 303-317.

Tivey, M.K., McDuff, R.E., 1990. Mineral precipitation in the walls of black smoke chimneys: a quantitative model of transport and chemical reaction. J. Geophys. Res 95 (B8), 12617-12637.

Tivey, M.K., Becker, E.L., Beinart, R., Fisher, C.R., Girguis, P.R., Langmuir, C.H., Michael, P.J., Reysenbach, A.-L., 2012. Links from mantle to microbe at the Lau Integrated Study Site: insights from a back-arc spreading center. Oceanography 25 (1), 62-77.

Tsurumi, M., 1998. The application of Geographical Information Systems to biological studies at hydrothermal vents. Cah. Biol. Mar. 39 (3-4), 263-266.

Tufar, W., 1989. Modern hydrothermal activity, formation of massive complex sulfide deposits and associated vent communities in the Manus back-arc basin (Bismarck Sea, Papua New Guinea). Mitt. Österr. Geol. Ges. 82, 183-210.

Zelnio, K.A., Rodriguez, E., Daly, M., 2009. Hexacorals (Anthozoa: Actiniaria, Zoanthidea) from hydrothermal vents in the south-western Pacific. Mar. Biol. Res. 5 (6), 547-571. 